\title{
Review
}

\section{Morphological, Hydrolytic and Thermal Properties of Legume Starches}

\author{
Adeleke Omodunbi Ashogbon ${ }^{\text {** }}$, Isaac Ayodele Ololade ${ }^{a}$, Yekini Deboh Aliub and \\ Adebowale Sayo Abitogunc \\ a Department of Chemistry and Industrial Chemistry, Adekunle Ajasin University, \\ Akungba-Akoko, Nigeria \\ ${ }^{\mathbf{b}}$ Department of Chemistry, University of Ibadan, Ibadan, Nigeria \\ 'Science Laboratory Technology Department, Rufus Giwa Polytechnic, Owo, Nigeria
}

(received June 3, 2010; revised May 31, 2011; accepted June 7, 2011)

\begin{abstract}
Legumes are an excellent source of carbohydrate and provide an inexpensive source of protein. With the exception of beach pea (12.3\%), the percentage yields of extracted legume starches fall within the range of $18.0-45.0 \%$ on a whole seed basis. The total lipid contents of legume starches range from $0.01-0.87 \%$. Legume starches have variable granule diameters, generally between 4 and $80 \mu \mathrm{m}$. Granule shape may be oval, spherical, elliptical or irregular, depending on the source. Legume starches exhibit a two-stage solubilization pattern; the rates of hydrolysis for the first and second stages are identical in some legume starches but differ in others. Most legume starches exhibit C-type X-ray diffraction patterns. The degrees of crystallinity of most legume starches are similar to, or slightly lower than, those of cereal starches. Most legume starches exhibit nearly identical gelatinization transition temperatures and enthalpies. However, their gelatinization temperature ranges $\left(T_{C}-T_{0}\right)$ differ. Legume starches easily retrograde due to their relatively high amylose contents, although long term retrogradation is attributed to short chains of amylopectin.
\end{abstract}

Keywords: legume, starch, granule morphology, hydrolysis, gelatinization, retrogradation, thermal properties, granule crystallinity

\section{Introduction}

The legume fruit is formed from a single carpel, which splits along the dorsal and the ventral sutures, and usually contains a row of seeds borne on the inner side of the ventral suture. Grain legumes are dicotyledonous seeds of plants that belong to the family Leguminosae having 16,000-19,000 species in approximately 750 genera (Allen and Allen, 1981). They rank fifth in terms of annual world grain production (171 million metric tons) after wheat, rice, corn and barley (FAO, 2003; Deshpande and Damodaran,1990). Approximately 12 species of the Leguminosae, which is the third largest family of flowering plants, are widely used as food (Chavan et al., 1999). Examples include lima bean, garbanzo bean, lentil bean, mung bean, pinto bean, adzuki bean, red kidney bean, smooth pea, wrinkled pea, and the two oilseed legumes, soybean and groundnut. The food legumes are rich in starch, protein, dietary fibre, minerals and water-soluble vitamins. Legumes constitute an important source of carbohydrates for a large part of human population, mainly in the

*Author for correspondence; E-mail: ashogbonwale @yahoo.com developing world. India is the largest producer and consumer of legumes in the world (Singh et al.,2008). The total carbohydrate contents of food legumes vary from $24 \%$ (winged bean) to 68\% (cowpea) (Ratnayake et al., 2001). Starch is the most abundant carbohydrate in the seed (22-45\%; Hoover and Sosulski, 1991). Legumes are used as food and feed (Leon et al., 1991) as the seed is a good source of both starch and protein, 36.7-50\% (Leon et al., 1989; Duke, 1981) and 29.7\% (Clemente et al., 2000; Menkov, 2000; Kessler, 1985), respectively. But lentil seeds contain more protein than other legume seeds, the protein content ranges from $24.3 \%$ to $30.2 \%$ for different cultivars (Wang and Daun, 2006). Variations in the values for the starch and protein contents of legumes reported in the literature may be attributed, in part, to differences in the methods of analyses.

A major factor which has an adverse effect on the widespread utilization of legume starches in the food industry is their relatively high amylose contents (Hoover and Sosulski, 1985). The association between amylose molecules and the outer branches of amylopectin in 
cooked starch pastes leads to extensive retrogradation, which results in cloudiness and syneresis, especially when legume starch gels are subjected to repeated freeze-thaw cycles (Hoover et al., 1988). The degree of syneresis seen in native legume starch gels would be unacceptable in most food products (Hoover et al., 1988). The physico-chemical properties and functional characteristics that are imparted by starches to aqueous systems and their uniqueness in various food applications vary with the biological origin (Svegmark and Hermansson, 1993). Starches contribute greatly to the textural properties of many foods and have many industrial applications as thickeners, colloidal stabilizers, gelling agents, bulking agents, water retention agents and adhesives (Singh et al., 2003). Methods used in the chemical analysis of legume starches are applicable to starches from other botanical sources.

Legume starches are usually extracted from the source using a procedure similar to that of Hoover and Sosulski (1985). Quantitative estimations of moisture, ash, nitrogen and damaged starch are performed by standard American Association of Cereal Chemists International (AACCI, 1984) or Association of Official Analytical Chemists International (AOACI, 1990) methods. Many methods of characterizing starch have been developed which could be used for screening large number of genotypes for unique properties (Kim et al., 1995). A large number of techniques, such as differential scanning calorimetry (DSC) (Donovan, 1979), X-ray diffraction (Zobel et al., 1988), small angle neutron scattering (Jenkins, 1994) and Kofler hot stage microscopy (Watson, 1964), have been used to study the gelatinization behavior of starches. Additionally, DSC is well suited to investigate the phase transitions of starch/water systems, for it allows the study of starch gelatinization over a wide range of starch/water ratios, determination of gelatinization temperatures above $100^{\circ} \mathrm{C}$ and estimation of transition enthalpies (Biliaderis et al., 1980). DSC has been used to study starch phase transitions from a physico-chemical approach (Donovan, 1979; Marchant and Blanshard, 1978; Lelievre, 1973). Biliaderis et al. (1980) studied legume starches specifically using DSC. Polarizing light microscopy had been used to determine the size, shape, and position of the hilum of common starches (McCrone and Delly, 1973; Schoch and Maywald, 1967; Reichert, 1913). The scanning electron microscope (SEM) is superior to the polarizing light microscope for the study of starch granule morphology. Advantages of SEM include a greater depth of focus and much higher resolution and magnification (Jane et al., 1994). SEM has been used to relate paste structures to paste properties (Fannon and BeMiller, 1992; Fannon et al., 1992a) and also to relate granule morphology to starch genotype (Fannon et al., 1992b). Many other studies involving scanning electron microscopy of starch granules have been reported in the literature (Fannon et al., 1990; Fitt and Snyder, 1984; Banks and Greenwood, 1975; Schoch and Maywald, 1967).

Wide angle X-ray diffraction has been applied to the study of legume starches (Davydova et al., 1995; Gernat et al., 1990; Hoover and Sosulski, 1985; Colonna et al., 1982). From DSC and X-ray studies, Bogracheva et al. (1998) were able to deduce a relationship between the ' $A$ ' and 'B' polymorphs of gelatinized legume starches. Identical methods were utilized for the calculation of the composition of 'A' and 'B' polymorphs of legume starches (Davydova et al., 1995). Other X-ray diffraction studies of starches have shown the dependence of starch crystallinity on amylose content, average chain length (CL) of amylopectin and the mole percentage of short chain fractions of amylopectin (Cheetham and Tao, 1997). The pasting and viscometric properties of starches have been studied with the Brabender visco-amylograph, the rapid visco-analyzer (RVA) and rotational viscometers (Wiesenborn et al., 1994).

Many researchers have used the dynamic rheometer for studying the viscoelastic or rheological properties of starches (Hsu et al., 2000; Tsai et al., 1997; Lii et al., 1996). Laser light scattering has been used to characterize granule diameter based on the assumption that granules are spherical (Wiesenborn et al., 1994). Unlike wide angle X-ray scattering (WAXS) which quantifies crystalline order throughout starch granules, small angle X-ray scattering (SAXS) quantifies differences (periodicity) at the level of amorphous-crystalline lamellae radiating from the hilum to the periphery of starch granules (Tester et al., 2000). More detailed discussion regarding the application of this technique to the investigation of structural, gelatinization and hydrothermal mechanisms of starches can be found in the literature.

In this review, information is presented on the yield, composition, swelling, morphological and thermal characteristics of legume starches.

Yield, composition and crystallinity. Data on the yield and composition of legume starches is presented in Table 1 . The purity of legume starches has been judged 
on the basis of composition and microscopic observation. The low nitrogen and ash contents and the absence of any adhering protein is related to the purity of the starches. With the exception of beach pea (12.3\%; Chavan et al., 1999), the yields fell within the range (18-45\%) reported by Hoover and Sosulski (1991) for most legume starches. The yield of great northern bean starch has been reported to be $18.2 \%$ (Sathe and Salunkhe, 1981). Naivikul and D’Appolonia (1979) reported yields of $40.3,38.3,39.9,42.5$ and $34.5 \%$ for navy bean, pinto bean, faba bean, lentil, and mung bean starches, respectively. Lineback and Ke (1975) obtained a starch yield of $37 \%$ from horse bean flour. Schoch and Maywald (1968) reported starch yields of 27, 38, and $37 \%$ from navy bean, lentil and mung bean, respectively. Differences in legume starch yield can be attributed, in part, to differences in the method of isolation. Difficulties in the isolation of starches from legumes have been attributed to the presence of a highly hydrated fine fiber fraction (Vose, 1977) which is derived from the cell wall enclosing the starch granules (Schoch and Maywald, 1968).Recently,the importance of lentil starches were re-emphasised and this had led to studies been conducted on them (Chung et al., 2009; Chung et al., 2008a; Lee et al.,2007).

Starch is one of the most abundant organic chemicals in the world. It is synthesized in the form of granules within cellular organelles (amyloplasts) and also found in the leaves of green plants in the plastids. The major polysaccharide of legume plants is starch. Starch consists of two polymers within its granules: amylose and amylopectin. Debranching (Takeda et al., 1992) and chain length (CL) studies (Shibanuma et al., 1994) on amylose have shown that the $\alpha$-(1-4)-linked glucose polymer is actually a mixture of linear and randomly limited branched polymers.

In contrast, amylopectin is a branched polymer with one of the highest molecular weights known among naturally occurring polymers (Abd Karim et al., 2000). Starch is semi-crystalline in nature with varying levels of crystallinity (Singh et al., 2003). The crystallinity is solely associated with the amylopectin component, while the amorphous regions mainly represent amylose (Zobel, 1988a, 1988b). Crystalline lamellae are made up of amylopectin double helices, which are packed in a parallel fashion, whereas the amylopectin branch points are in the amorphous zones (Jacobs and Delcour, 1998). Using SAXS and neutron scattering, a periodicity of $9-11 \mathrm{~nm}$ has been found for starches from various botanical sources (Jenkins et al., 1993; Cameron and Donald, 1992; Oostergetel and Van Bruggen, 1989; Blanshard et al., 1984;Muhr et al., 1984; Sterling, 1962). Kassenbeck (1978) and Yamaguchi et al. (1979) attributed the periodicity to the repeat distances of crystalline and amorphous lamellae.

The amylose content of starch varies with the botanical source (Table 1) and is affected by the climatic conditions and soil type during growth (Morrison and Azudin, 1987; Asaoka et al., 1985; Morrison et al., 1984; Inatsu et al., 1974; Juliano et al., 1964). Apart from Table 1, recent studies show that apparent amylose content of field pea,kidney bean,chickpea,blackgram,pigeon pea and mung bean starches to be $39.9 \%, 36.0 \%$, 34.4$35.5 \%, 32.9-35.6 \%, 38.0-41.5 \%$ and $31.7-33.8 \%$ respectively (Chung et al., 2008b; Nishinari,2008; Kim et al.,2007;Tan et al.,2006). In contrast,the apparent amylose concentration of chickpea starches varies from $28 \%$ to $40 \%$ (Hughes et al., 2009; Singh et al., 2004) and that of smooth pea and wrinkled pea starches vary from $30-40 \%$ and $60-76 \%$, respectively (Ratnayake et al., 2002). Limited co-crystallization between amylose and amylopectin has been suggested by Blanshard (1987) and Jenkins and Donald (1995). WAXS has revealed three forms of packing of amylopectin double helices, A, B, and C crystal types, and the features of starch ${ }^{13} \mathrm{C} \mathrm{CP} / \mathrm{MAS}$ (solid state ${ }^{13} \mathrm{C}$ cross polarization/magic angle spinning) spectra are consistent with starch being a combination of amorphous (single chain) and ordered (double-helix components) material (Gidley and Bociek, 1985). Legume starches exhibit the typical mixed-state pattern ' $\mathrm{C}$ '. Many studies tend to show that the 'C-type' pattern is characteristic of all legume starches. Beach pea, green pea and grass pea starches (Hoover et al., 1997; Hoover and Manuel, 1996; Gernat et al., 1990; Hoover and Sosulski, 1985; Colonna et al., 1981), field pea starches (Davydova et al., 1995; Gernat et al., 1990; Hoover and Sosulski, 1985; Colonna et al., 1982), mung bean starches (Tan et al., 2009), lentil starches (Sodhi et al., 2009), chickpea starches (Polesi et al., 2011) and black gram starches (Singh et al., 2004) all showed the characteristic 'C-type' pattern of legume starches. However, these X-ray patterns of legume starches were characterized by different intensities. In general, most legume starches exhibit C-type X-ray diffraction patterns characterized by two very distinct intensity lines at 17.2 and $18.1^{\circ}(2 \square)$ angles (Table 2). The differences in X-ray intensities were attributed to the manner in which the double helices 
are arranged within the crystalline domains of the granule (Chavan et al., 1999). According to Gernat et al. (1990), the legume starch 'C' crystalline polymorph is a mixture of ' $A$ ' and ' $B$ ' unit cells, and that these starches contain pure ' $A$ ' and ' $B$ ' polymorphs in varying proportions. Both ' $A$ ' and ' $B$ ' type starches are based on parallel stranded double helices, in which the helices are closely packed in the ' $A$ ' type starch but loosely packed in the 'B' type starch (Ratnayake et al., 2001). Bogracheva et al. (1998) reported from studies of gelatinized pea starch that the 'A' and ' $\mathrm{B}$ ' polymorphs are present in the same granule and that the ' $\mathrm{B}$ ' polymorph is situated in the centre of all granules surrounded by the ' $\mathrm{A}$ ' polymorph.

Table 2 shows some of the $\mathrm{X}$-ray diffraction behaviours of some legume and other starches. Legume starches generally have higher amylose content than non-legume starches (Hoover and Manuel, 1995; Gernat et al., 1990; Hoover and Sosulski, 1985; Colonna et al., 1981). The degrees of crystallinity of most legume starches, such as broad bean (18.5\%), smooth pea (18.9\%) and wrinkled pea (15.4-16.0\%) are similar to, or slightly lower than, those of cereal starches (Table 2). The degrees of crystallinity of wheat, maize, waxy maize and amylomaize starches are 19.5, 21.8, 31.0 and $17.0 \%$, respectively (Gernat et al.,1993; Gernat et al., 1990).

Navy bean, pinto bean, faba bean, lentil and mung bean starch granules exhibited similar birefringence characteristics in polarized-light photomicrographs (Naivikal and D’ Appolonia, 1979).
Starch paste behavior in aqueous systems depends on the chemical and physical characteristics of the starch granules, such as mean granule size, granule size distribution, amylose/amylopectin ratio and mineral content (Madsen and Christensen, 1996). Morrison et al. (1993a,b) reported the presence in starches of two amorphous forms of amylose, namely lipid-free amylose and lipid-complexed amylose. Both forms of amylose are found in legume starches. The amylose content of native legume starches (Table 1) is generally higher than that of unmodified cereal and tuber starches. This association of legume starches with high amylose content explains their higher degree of retrogradation and syneresis compared to either cereal or tuber starches. Ratnayake et al. (2001) reported the amylose contents of four cultivars of field pea (Pisum sativum L.) to be in the range of $48.8-49.6 \%$ (Table 1 ). These values were much higher than those reported by Chavan et al. (1999) for beach pea (29.0\%), green pea (36.7\%), grass pea (36.0\%) starches (Table 1), and lower than those of smooth pea (52.6-57.0\%) and wrinkled pea (94.0\%) (Czuchajowska et al., 1998), but comparable to that of mung bean starch (45.3\%; Hoover et al., 1997) (a different sample than that described in Table 1).More contradicting is that amylose content of $40.69 \%$ was proposed for mung bean starch (MBS) by Thao and Noomhorm (2011) while Li and Gao (2010) indicated a different value of $27.73 \%$ for MBS. Biliaderis et al. (1980) reported the amylose content of MBS to be

Table1. Chemical composition of some legume starches.

\begin{tabular}{lllllll}
\hline \hline Legume & Phosphorus & Amylose & Fat & Yield & Ash & Nitrogen \\
\cline { 2 - 7 } & \multicolumn{7}{c}{$(\%)$} \\
\hline Adzuki bean & $0.013^{\mathrm{a}}$ & $34.9^{\mathrm{a}}$ & $0.60^{\mathrm{h}}$ & $21.5^{\mathrm{i}}$ & - & - \\
Smooth pea & $0.006^{\mathrm{a}}$ & $33.1^{\mathrm{a}}$ & - & - & - & - \\
Garbanzo bean & $0.010^{\mathrm{a}}$ & $34.1^{\mathrm{a}}$ & $0.11-0.12^{\mathrm{g}}$ & $38.0-40.0^{\mathrm{j}}$ & $0.042-0.053^{\mathrm{j}}$ & $0.044-0.047^{\mathrm{j}}$ \\
Red kidney bean & $0.016^{\mathrm{a}}$ & $35.0^{\mathrm{a}}$ & - & - & - & - \\
Lentil & $0.008^{\mathrm{a}}$ & $45.5^{\mathrm{a}}$ & $0.27-0.38^{\mathrm{f}}$ & $42.5^{\mathrm{i}}$ & $0.054-0.060^{\mathrm{j}}$ & $0.031^{\mathrm{j}}$ \\
Navy bean & $0.011^{\mathrm{a}}$ & $36.0^{\mathrm{a}}$ & $0.11^{\mathrm{g}}$ & $40.3^{\mathrm{i}}$ & $0.051^{\mathrm{j}}$ & $0.041-0.046$ \\
Mung bean & $0.016^{\mathrm{a}}$ & $34.9^{\mathrm{a}}$ & $0.32^{\mathrm{e}}$ & $34.5^{\mathrm{i}}$ & - & - \\
Faba bean & $0.010^{\mathrm{a}}$ & $32.5^{\mathrm{a}}$ & - & $39.9^{\mathrm{i}}$ & - & - \\
Lima bean & - & $32.6^{\mathrm{b}}$ & $0.54^{\mathrm{b}}$ & $23.0-30.0^{\mathrm{j}}$ & $0.14^{\mathrm{b}}$ & $0.036-0.070$ \\
Field pea & - & $48.8-49.6^{\mathrm{c}}$ & $0.28-0.34^{\mathrm{c}}$ & $32.7-33.5^{\mathrm{c}}$ & $0.03-0.14^{\mathrm{c}}$ & $0.04-0.07^{\mathrm{c}}$ \\
Beach pea & - & $29.02^{\mathrm{d}}$ & $0.16^{\mathrm{d}}$ & $12.3^{\mathrm{d}}$ & $0.22^{\mathrm{d}}$ & $0.08^{\mathrm{d}}$ \\
Green pea & - & $36.70^{\mathrm{d}}$ & $0.19^{\mathrm{d}}$ & $30.0^{\mathrm{d}}$ & $0.07^{\mathrm{d}}$ & $0.09^{\mathrm{d}}$ \\
Grass pea & - & $36.37^{\mathrm{d}}$ & $0.12^{\mathrm{d}}$ & $26.0^{\mathrm{d}}$ & $0.05^{\mathrm{d}}$ & $0.07^{\mathrm{d}}$ \\
\hline \hline
\end{tabular}

${ }^{\mathrm{a}}$ Biliaderis et al., 1980; ${ }^{\mathrm{b}}$ Betancur-Ancona et al., 2003; ' Ratnayake et al., 2001; ${ }^{\mathrm{d}}$ Chavan et al., 1999; ${ }^{\mathrm{e}}$ Hoover et al., 1997; ${ }^{\mathrm{f}}$ Hoover and Manuel, 1995; ${ }^{\mathrm{g}}$ Hoover et al., 1988; ${ }^{\mathrm{h}}$ Tjahjadi and Breene, 1984; ${ }^{\mathrm{i}}$ Naivikul and D’Appolonia, 1979; j Schoch and May wald, 1968. 
34.9\% (Table 1). Tjahjadi and Breene (1984) reported a rather low value of $28.8 \%$ for the amylose content of adzuki bean. Other researchers (Biliaderis et al., 1980; 1979) reported a value of $34.9 \%$ for the amylose content of adzuki bean. The different values for the amylose content of the same starch (e.g. mung bean starch and adzuki bean starch) show that the literature is replete with conflicting information with respect to the amylose contents of legume starches. The reported variations in amylose content have been attributed to differences in variety and to the use of different starch isolation procedures and to different methods of analysis, i.e., colorimetry versus potentiometry (Kim et al., 1995; Naivikul and D'Appolonia, 1979). The activity of the enzymes involved in starch biosynthesis may also be responsible for the variations in amylose content among starches (Krossmann and Lloyd, 2000).

Minor constituents commonly found in starch include lipids, proteins, phosphorus and other minerals (Ca, K, Mg and Zn) (Ellis et al., 1998). Although the proportion of amylose and amylopectin and their properties are paramount in determining the characteristics of the starch, minor constituents of the starch granule seem to affect the properties relevant to its use in food and non-food applications. These minor constituents are materials that are associated with the surface of the granule or are true internal components.Protein has been classified as either surface protein or integral protein, and its association with starch granules varies in amount between and within species (Ellis et al., 1998). One of the granule surface proteins, friablin, has been linked with kernel hardness in wheat (Anjum and Walker, 1991). Lipids associated with legume starch granules have been found to occur on the surface, as well as inside the granule (Morrison, 1981). The surface lipids are principally triglycerides, but also include free fatty acids, glycolipids and phospholipids (Vasanthan and Hoover, 1992; Galliard and Bowler, 1987; Morrison, 1981). Vasanthan and Hoover (1992), Morrison (1981) and Hargin and Morrison (1980) each reported that the internal lipids were predominantly monoacyl lipids with the major components being lysophospholipids and free fatty acids. The total lipid contents of legume starches were found to be in the range of $0.01-0.87 \%$ (Hoover and Sosulski, 1991). All of the values shown in Table 1 for the total lipid contents of different legume starches fall within the stated range. Morrison (1981) and Mikus et al. (1946) postulated that starch lipids may be present in the free state or bound to starch components, either linked via ionic or hydrogen bonding to hydroxyl groups of the starch components or in the form of amylose inclusion complexes in which the ligand resides within the central hydrophobic core of the helix. Total lipid contents of $0.28-0.34 \%$ have been ascribed to field pea starches (Table 1; Ratnayake et al., 2001) and this is similar to the range reported for mung bean $(0.32 \%$; Hoover et al., 1997), and lentil (0.27-0.38\%; Hoover and Manuel, 1995) starches, but higher than that reported for beach pea $(0.16 \%)$, green pea $(0.19 \%)$ grass pea (0.12\%) starches (Chavan et al., 1999) and chickpea (0.01\%) starches (Hoover and Ratnayake,2002). The discrepancies in the lipid contents of the legume starches described above may be due to various reasons. Many researchers (Kawano et al., 1989; Goshima et al., 1985; Maningat and Juliano, 1980; Melvin, 1979; Lorenz, 1976; Goering et al., 1975; Medcalf et al., 1968) have used different lipid extractants, which differ in their ability to extract firmly bound lipids (Vasanthan and Hoover, 1992; Morrison and Coventry, 1985; Morrison, 1981). Because of the utilization of different solvents for the extraction of total lipids (both surface and internal) from legume starches, it is difficult to compare results from different published data. Additionally, some solvent systems utilized have proved ineffective in the removal of internal starch lipids. The same is true for bound lipids, especially those complexed with amylose. Controversy still exists with regard to lipid binding ability to the short linear (15-20 glucose units) portions of the outer branches of amylopectin (Eliasson and Ljunger, 1988a; Gidley and Bociek, 1988; Biliaderis and Vaughan, 1987; Hahn and Hood, 1987; Evans, 1986; Destefanis et al., 1977; Goering et al., 1975; Krog, 1971; Lagendijk and Pennings, 1970). Internal lipid content increases with amylose content, and unless the granule integrity is disrupted, the lipids remain inaccessible to normal fat solvents, suggesting that they are present as an amylose inclusion complex. There is limited information in the literature on minor constituents of legume starches as compared to what is available regarding cereal and tuber starches.

Swelling, solubility and hydrolysis. Starch granule swelling is known to begin in the bulk, relatively mobile, amorphous fraction and in the more restrained amorphous regions immediately adjacent to the crystalline region (Donovan, 1979). Leach et al. (1959) postulated that the bonding forces within the starch granule influence the extent of swelling. Thus, highly associated starch granules should be relatively resistant to swelling and amylose 
leaching (Vasanthan and Hoover, 1992). Furthermore, the swelling factor (SF) has been shown to be influenced by amylose-lipid complexes (Hoover and Manuel, 1995, 1996; Tester et al., 1993). The swelling power and amylose leaching (AML) of pea starches increased with increasing temperature (Table 3). Chavan et al. (1999) and Ratnayake et al. (2001) investigated the SF and AML of pea starches over the temperature range of $50-95^{\circ} \mathrm{C}$. Ratnayake et al. (2001) found no significant differences in the SF of starches from four cultivars (Curneval, Carrera, Grande and Keoma) of field pea (Pisum sativum L.) (Table 3).

These authors showed that the SFs (at $95^{\circ} \mathrm{C}$ ) of field pea starches were lower than those reported for beach pea (30.72), green pea (34.1) (Chavan et al., 1999), mung bean (43.6) and gold lentil (31.0) starches, but was comparable to that of Laird lentil starch (26.0) (Hoover and Manuel, 1995). They also reported that the AML values of field pea cultivars at $95^{\circ} \mathrm{C}$ (Table 4) were much higher than those reported by (Chavan et al., 1999) for beach pea (12.94), green pea (17.08), grass pea (19.07), but lower than those reported for gold lentil (35.5) and Laird lentil (38.5) starches (Hoover and Manuel, 1995).

In all four starches studied by Ratnayake et al. (2001), SF and AML increased dramatically between 60 and $85^{\circ} \mathrm{C}$ (Table 4); thereafter, the increase were gradual. An identical trend has been observed for other legume starches (Chavan et al., 1999; Hoover and Manuel,

Table 2. X-ray diffraction patterns of some legume and other starches

\begin{tabular}{|c|c|c|c|c|c|c|c|}
\hline \multirow{2}{*}{$\begin{array}{l}\text { Starch source } \\
\text { Maize starch (Type A) }\end{array}$} & \multicolumn{2}{|c|}{$\begin{array}{l}\text { Moisture } \\
\text { content (\%) }\end{array}$} & \multicolumn{4}{|c|}{ Diffraction angle ( $\square$ ) } & \multirow{2}{*}{$\begin{array}{l}\text { Source } \\
\text { (Gernat et al., 1990) }\end{array}$} \\
\hline & N.A. & $23.0^{\text {vs }}$ & $18.0^{\mathrm{m}}$ & $17.2^{\mathrm{m}}$ & $15.1^{\mathrm{s}}$ & & \\
\hline Potato starch (Type B) & N.A. & $24.0^{\mathrm{m}}$ & $22.0^{\mathrm{m}}$ & $17.2^{\mathrm{vs}}$ & $13.5^{\mathrm{m}}$ & $5.4^{\mathrm{vs}}$ & (Gernat et al., 1990) \\
\hline Kidney bean & 10.3 & $23.0^{\mathrm{s}}$ & $21.4^{\mathrm{w}}$ & $17.8^{\text {vs }}$ & $17.2^{\mathrm{vs}}$ & & (Hoover and Sosulski, 1985) \\
\hline Northern bean & 10.5 & $22.9^{\mathrm{s}}$ & - & $17.2^{\mathrm{vs}}$ & $15.3^{\mathrm{m}}$ & & (Hoover and Sosulski, 1985) \\
\hline Pinto bean & 10.4 & $23.0^{\text {vs }}$ & $18.0^{\text {vs }}$ & $17.2^{\mathrm{vs}}$ & $15.1^{\mathrm{m}}$ & & (Hoover and Sosulski, 1985) \\
\hline Navy bean & 10.7 & $22.9^{\mathrm{s}}$ & $17.8^{\mathrm{vs}}$ & $17.2^{\mathrm{vs}}$ & $15.3^{\mathrm{w}}$ & & (Hoover and Sosulski, 1985) \\
\hline Black bean & 10.4 & $23.1^{\mathrm{s}}$ & $17.8^{\mathrm{vs}}$ & $17.2^{\mathrm{vs}}$ & $15.3^{\mathrm{w}}$ & & (Hoover and Sosulski, 1985) \\
\hline Broad bean & 14.0 & $24.0^{\mathrm{s}}$ & - & $17.0^{\text {vs }}$ & $15.1^{\mathrm{m}}$ & & (Colonna et al., 1981) \\
\hline Smooth pea & 15.9 & $23.0^{\mathrm{w}}$ & - & $17.0^{\mathrm{vs}}$ & $15.1^{\mathrm{m}}$ & $5.5^{\mathrm{m}}$ & (Colonna et al., 1981) \\
\hline Lentil & 9.7 & $23.0^{\mathrm{m}}$ & - & $17.2^{\mathrm{m}}$ & $13.4^{\mathrm{w}}$ & & $\begin{array}{l}\text { (Hoover and Sosulski, 1986; } \\
\text { Hoover and Manuel, 1995) }\end{array}$ \\
\hline Field pea & 9.8 & $23.0^{5}$ & - & $17.2^{\mathrm{s}}$ & $13.4^{\mathrm{w}}$ & & (Hoover and Sosulski, 1986) \\
\hline Adzuki bean & N.A. & $24.0^{5}$ & $18.0^{\text {vs }}$ & $17.0^{\mathrm{vs}}$ & $15.0^{\mathrm{s}}$ & & (Biliaderis et al., 1981) \\
\hline Wrinkled pea & N.A. & $24.0^{\mathrm{m}}$ & $20.0^{\mathrm{m}}$ & $17.0^{\text {vs }}$ & $15.0^{\mathrm{m}}$ & $5.5^{\mathrm{m}}$ & (Biliaderis et al., 1981) \\
\hline
\end{tabular}

${ }^{\mathrm{vs}}=$ very strong intensity; ${ }^{\mathrm{s}}=$ strong intensity; $^{\mathrm{m}}=$ medium intensity; and $^{\mathrm{w}}=$ weak intensity.

Table 3. Swelling factors (SF) and amylose leaching (AML) values for beach pea, green pea and grass pea starches at different temperatures ${ }^{1,2}$ (Chavan et al., 1999)

\begin{tabular}{llllllll}
\hline \hline $\begin{array}{l}\text { Temp. } \\
\left({ }^{\circ} \mathrm{C}\right)\end{array}$ & Beach pea & Green pea & Grass pea & & Beach pea & Green pea & Grass pea \\
\hline 50 & $7.33 \pm 0.17^{\mathrm{a}}$ & $7.52 \pm 1.01^{\mathrm{a}}$ & $1.42 \pm 0.14^{\mathrm{b}}$ & $*$ & $*$ & $*$ \\
60 & $8.55 \pm 0.05^{\mathrm{a}}$ & $8.94 \pm 1.08^{\mathrm{a}}$ & $1.56 \pm 0.14^{\mathrm{b}}$ & $*$ & $*$ & $*$ \\
70 & $16.73 \pm 0.18^{\mathrm{a}}$ & $17.9 \pm 1.06^{\mathrm{a}}$ & $10.02 \pm 0.08^{\mathrm{b}}$ & & $3.43 \pm 0.03^{\mathrm{b}}$ & $6.16 \pm 1.09^{\mathrm{a}}$ & $6.25 \pm 0.09^{\mathrm{a}}$ \\
80 & $18.43 \pm 0.10^{\mathrm{b}}$ & $21.11 \pm 1.07^{\mathrm{a}}$ & $13.03 \pm 0.07^{\mathrm{c}}$ & & $7.54 \pm 0.08^{\mathrm{b}}$ & $14.33 \pm 1.03^{\mathrm{a}}$ & $15.07 \pm 0.54^{\mathrm{a}}$ \\
85 & $19.61 \pm 0.13^{\mathrm{b}}$ & $22.41 \pm 1.03^{\mathrm{a}}$ & $14.90 \pm 0.07^{\mathrm{c}}$ & & $9.84 \pm 0.29^{\mathrm{b}}$ & $15.08 \pm 1.10^{\mathrm{a}}$ & $15.66 \pm 0.53^{\mathrm{a}}$ \\
90 & $24.92 \pm 0.21^{\mathrm{b}}$ & $28.01 \pm 0.37^{\mathrm{a}}$ & $19.58 \pm 0.13^{\mathrm{c}}$ & & $11.55 \pm 0.52^{\mathrm{b}}$ & $16.69 \pm 1.02^{\mathrm{a}}$ & $17.68 \pm 0.10^{\mathrm{a}}$ \\
95 & $30.72 \pm 0.82^{\mathrm{b}}$ & $34.13 \pm 0.24^{\mathrm{a}}$ & $26.01 \pm 0.07^{\mathrm{c}}$ & & $12.94 \pm 0.18^{\mathrm{b}}$ & $17.08 \pm 1.59^{\mathrm{a}}$ & $19.07 \pm 0.13^{\mathrm{a}}$ \\
\hline
\end{tabular}

$1=$ The data represent means of four determinations \pm SD. Means in each row with different superscripts are significantly different $(\mathrm{p}<0.05){ }^{2}=$ Swelling factor is ratio of volumes of wet to dry granules; $*$ = Amylose leaching was not observed at these temperatures. 
Table 4. Swelling factors (SF) and amylose leaching (AML) values for field pea starches at different temperatures (Ratnayake et al., 2001)

\begin{tabular}{llllllll}
\hline \hline Starch source & \multicolumn{7}{c}{ Temperature $\left({ }^{\circ} \mathrm{C}\right)$} \\
\cline { 2 - 7 } & 50 & 60 & 70 & 80 & 85 & 90 & 95 \\
\hline Carneval SF & $4.2 \pm 0.21$ & $8.5 \pm 0.25$ & $13.7 \pm 0.16$ & $19.4 \pm 0.11$ & $24.3 \pm 0.04$ & $26.5 \pm 0.03$ & $26.7 \pm 0.21$ \\
AML & $0.0 \pm 0.00$ & $10.5 \pm 0.23^{\mathrm{q}}$ & $16.3 \pm 0.17^{\mathrm{q}, \mathrm{r}}$ & $19.6 \pm 0.12^{\mathrm{q}}$ & $25.1 \pm 0.03$ & $26.3 \pm 0.22^{\mathrm{q}}$ & $26.6 \pm 0.16^{\mathrm{q}, \mathrm{r}}$ \\
Carrera SF & $4.2 \pm 0.22$ & $8.6 \pm 0.21$ & $13.8 \pm 0.22^{\mathrm{p}}$ & $19.4 \pm 0.05$ & $24.2 \pm 0.05$ & $26.4 \pm 0.21$ & $26.7 \pm 0.24$ \\
AML & $0.0 \pm 0.00$ & $10.1 \pm 0.22^{\mathrm{p}}$ & $15.1 \pm 0.12^{\mathrm{p}}$ & $18.1 \pm 0.25^{\mathrm{p}}$ & $24.8 \pm 0.24^{\mathrm{p}}$ & $25.1 \pm 0.19^{\mathrm{p}}$ & $25.2 \pm 0.10^{\mathrm{p}}$ \\
Grande SF & $4.1 \pm 0.21$ & $8.4 \pm 0.22$ & $13.8 \pm 0.11$ & $19.4 \pm 0.10$ & $24.2 \pm 0.05$ & $26.5 \pm 0.16$ & $26.7 \pm 0.23$ \\
AML & $0.0 \pm 0.00$ & $10.5 \pm 0.23^{\mathrm{q}}$ & $16.0 \pm 0.10^{\mathrm{q}}$ & $20.2 \pm 0.08^{\mathrm{r}}$ & $25.7 \pm 0.10^{\mathrm{r}}$ & $26.0 \pm 0.12^{\mathrm{q}}$ & $26.2 \pm 0.09^{\mathrm{q}}$ \\
Keoma SF & $4.1 \pm 0.18$ & $8.4 \pm 0.22$ & $13.3 \pm 0.11$ & $19.2 \pm 0.20$ & $24.1 \pm 0.20$ & $26.4 \pm 0.20$ & $26.5 \pm 0.05$ \\
AML & $0.0 \pm 0.00$ & $10.7 \pm 0.15^{\mathrm{q}}$ & $16.6 \pm 0.20^{\mathrm{r}}$ & $20.3 \pm 0.06^{\mathrm{r}}$ & $25.5 \pm 0.16^{\mathrm{r}}$ & $26.6 \pm 0.20^{\mathrm{r}}$ & $26.8 \pm 0.02^{\mathrm{r}}$ \\
\hline \hline
\end{tabular}

Values for AML followed by the same letter, in the same column, are not significantly different $(\mathrm{P}<0.05)$ by Tukey's HSD test. No significant differences $(\mathrm{P}<0.05)$ were observed among values for SF within the same column by Tukey's HSD test (Ratnayake et al., 2001).

1995; Hoover and Sosulski, 1985; Tolmasquim et al., 1971; Schoch and Maywald, 1968). Ratnayake et al., (2001) suggested that the rapid increases in SF and AML of four cultivars of field pea starches, between 60 and $85^{\circ} \mathrm{C}$ (Table 4), were probably due to an increase in molecular mobility of the amorphous region, which causes unraveling and melting of the double helices present within the amorphous and crystalline domains. Other authors (Chavan et al., 1999) suggested that SF was determined by interactions between amylose chains within the amorphous domains of the granule and suggested that AML in these legume starches (beach pea, green pea and grass pea) (Table 3 ) is influenced by the interplay between differences in amylose content and bound lipid content and by the magnitude of the interactions between amylose chains within the native granule. When starch molecules are heated in excess water, the crystalline structure is disrupted and water molecules become linked by hydrogen bonding to the exposed hydroxyl groups of amylose and amylopectin, which causes an increase in granule swelling and solubility (Singh et al., 2003). The presence of lipids in starch may have a reducing effect on the swelling of the individual granules (Galliard and Bowler, 1987). Swelling power and solubility provide evidence of the magnitude of the interactions between starch chains within the amorphous and crystalline domains. The extent of this interaction is influenced by the amylose to amylopectin ratio and by the characteristics of amylose and amylopectin in terms of molecular weight distribution, degree and length of branching, and conformation (Hoover, 2001). Differences in the swelling and solubility behaviour of starches from different botanical sources, and of starches from different cultivars of a botanical source, are caused by differences in amylose and lipid content, as well as in granule organization (Singh et al., 2003).

Many researchers (Chavan et al., 2010; Kevate et al., 2010; Chavan et al., 2009; Ratnayake et al., 2001; Chavan et al., 1999; Biliaderis et al., 1980) hydrolysed legume starches (smooth pea, wrinkled pea, adzuki bean, mung bean, red kidney bean, green lentil, field pea, beach pea, green pea, grass pea,moth bean,rice bean and horse gram) with $2.2 \mathrm{~N} \mathrm{HCl}$ and found that they all exhibited a two-stage solubilization pattern. The same two-stage hydrolysis pattern has also been reported for corn, waxy corn, wheat, potato and rice starches (Robin et al., 1974, 1975). These authors reported a relatively fast rate of hydrolysis during the first eight or ten days, followed by a slower rate between ten and twenty days. The faster first stage corresponds to the hydrolysis or degradation of the more amorphous parts of the starch granule (Cairns et al., 1990; Biliaderis et al., 1981; Kainuma and French, 1971). The slow degradation during the second stage has been attributed to the erosion of the crystalline material (Robin et al., 1974; Kainuma and French, 1971). Despite the twostage solubilization pattern, the rates of hydrolysis for the first and second stages were identical in some legume starches but differed in others. Ratnayake et al. (2001) investigated the acid hydrolysis of starch from four cultivars (Carneval, Carrera, Grande and Keoma) of field pea. They observed no significant differences in the extent of hydrolysis among the starches during the first eigt days and further showed that at the end of 20 days, the legume starches were hydrolyzed to the same 
extent. Identical rates of hydrolysis of starch in the first solubilization stage has been attributed to similar degrees of packing and orientation of the starch chains in the amorphous regions (Ratnayake et al., 2001). Chavan et al. (1999) and Hoover and Manuel (1995) reported comparable extents of hydrolysis for other legume starches.

The identical kinetics of the second solubilization stage (from 10 to 20 days) has been attributed to similar amounts of double helices within the crystalline region, and similar crystallite size, in all four starches. In contrast, Chavan et al. (1999) hydrolyzed legume (beach pea, grass pea and green pea) starches with $2.2 \mathrm{~N} \mathrm{HCl}$ and reported differences in the two-stage solubilization pattern.

It seems the differences in the susceptibility towards acid hydrolysis during the first 10 days is influenced by the interplay of bound-lipid content and amylose chain associations within the amorphous domains of the starch granule (Chavan et al., 1999). Morrison et al. (1993) have shown by studies on lintnerized barley starches that lipid-complexed amylose chains are resistant to acid hydrolysis. To account for the slower hydrolysis rate of the crystalline parts of the starch granule, several hypotheses have been proposed (Hoover and Manuel, 1996; Kainuma and French 1971; BeMiller, 1965). Firstly, it has been suggested that the dense packing of starch chains within the starch crystallites does not readily allow the penetration of $\mathrm{H}_{3} \mathrm{O}^{+}$into these regions. Secondly, a change in conformation of D-glucopyranose units (from chair to half chair) is a pre-requisite for hydrolysis of glucosidic bonds by $\mathrm{H}_{3} \mathrm{O}^{+}$. Additionally, these transformations in conformation could be more difficult in amylosecomplexed lipid chains, due to a decrease in chain flexibility. The crystalline regions (consisting basically of double helices of external A and B chains of amylopectin) are generally less accessible than the amorphous regions to attack by hydrated protons (Cairns et al., 1990; Robin et al., 1974; Kainuma and French, 1971) due to dense packing of starch chains within the starch crystallites and to the high energy of activation (Wu and Sarko, 1978) required to cause the conformational change of the glucose units (within the starch crystallites) from chair to half chair (a prerequisite for acid hydrolysis).

Morphological properties. Amylose and amylopectin molecules are arranged together in a relatively waterinsoluble granule of definitive size, shape and morphological characteristics peculiar to a particular plant source (Jane et al., 1994). Variation in the size and shape of starch granules is attributed to differences in biological origin (Svegmark and Harmansson, 1993), genotype and cultural practices (Singh et al., 2003), and maturity (Manners, 1974). The morphology of starch granules depends on the biochemistry of the chloroplast or amyloplast, as well as the physiology of the plant (Badenhuizen, 1969). The shape of the starch granule is also influenced by the growth environment (Hizukuri, 1969).

Many researchers (Fannon et al., 1990; Fitt and Synder, 1984; Banks and Greenwood, 1975; Schoch and Maywald, 1967) have studied and identified starch granules with SEM, and other researchers (McCrone and Delly, 1973; Reichert, 1913) did the same with light microscopy. The size, shape, and position of the hilum of legume starch granules has been observed most often using polarized light microscopy or scanning electron microscopy (SEM). SEM showed field pea starch granules from four cultivars (Carneval, Carrea, Grande and Keoma) to have irregular shapes, which varied from round (5-7 $\mu \mathrm{m}$ ) to elliptical (shorter diameter, $10 \mu \mathrm{m}$; longer diameter, $25 \mu \mathrm{m}$; Ratnayake et al., 2001). These values were lower than those reported for other legume starches (Czuchajowska et al., 1998; Hoover and Sosulski, 1991). Microscopic examination showed that beach pea, green pea and grass pea starch granules had irregular shapes, which varied from round (6-33 $\mu \mathrm{m}$ ) to elliptical (shorter diameter, 11-22 $\mu \mathrm{m}$; longer diameter, 17-35 $\mu \mathrm{m}$; Chavan et al.,1999). The surfaces of pea starch granules appeared smooth and showed no evidence of fissures when viewed by SEM (Miao et al.,2009; Ratnayake et al., 2001; Chavan et al., 1999). Other researchers (Liu and Shen,2007 ; Tan et al.,2007) indicated that MBS granule ranged from 6.5 to $43.4 \mu \mathrm{m}$ in dimension and $14-15 \mu \mathrm{m}$ in width, $18-21 \mu \mathrm{m}$ in length with oblong or kidney-like shape (Liu and Shen, 2007). According to Tjahjadi and Breene (1984), the granules of adzuki bean starch were mostly oval to kidney shaped, although some were irregular in shape, when viewed under the light microscope. Scanning electron micrographs of these granules revealed that the fissures extended to the surfaces of the granules (Tjahjadi and Breene, 1984). These surface irregularities appeared to be characteristic of adzuki bean starch granules and presumably caused by the way the granules are packed within the protein matrix of the cotyledon (Lineback and Ke, 1975). The size of the adzuki starch granules 
ranged from 15-45 $\mu \mathrm{m}$ with an average size of $32 \mu \mathrm{m}$ (Tjahjadi and Breene, 1984). These authors also reported that the granules possessed striae and centric positioned hila. Jane et al. (1994) extensively studied starch granule morphology using SEM. These authors used a magnification of x1500 and emphasized the importance of identical magnification with SEM for the purpose of comparing observations of starch granules from different studies. Bean and pea starches are characterized as thick disks with a 'cut' around the middle or at the end and an indentation at one end. The actual cause for the individual characteristics and morphologies are not known, but obvious factors are genetical control, types and amounts of synthetic enzymes in the biosynthesis of the starch molecules, membranous structure of the amyloplast organelle, and arrangement and association of starch molecules (Jane et al., 1994). Physicochemical properties, such as percent light transmittance, amylose content, swelling power and water-binding capacity, were significantly correlated with the average granule size of starches separated from different plant sources (Kaur et al., 2002; Singh and Singh, 2001; Zhou et al., 1998).

In general, starches isolated from legumes have variable granule dimensions, ranging from 4-80 $\mu \mathrm{m}$ (Table 5). The shape of the granules varies from oval, spherical, round and elliptical to irregularly shaped, depending on the source of the starch (Hoover and Sosulski, 1991). Mung bean and black bean have relatively small starch granules (Table 5).

Gelatinization and retrogradation properties. When the starch granule is heated up to the gelatinization temperature in excess water, heat transfer and moisture

Table 5. Physical dimensions of granules of some legume starches (Hoover and Sosulski, 1991)

\begin{tabular}{lllll}
\hline \hline Starch source & \multicolumn{3}{c}{ Range (diameter) } & \multicolumn{1}{c}{ Shape } \\
\cline { 2 - 4 } & $\begin{array}{l}\text { Width } \\
(\mu \mathrm{m})\end{array}$ & $\begin{array}{l}\text { Length Unspecified } \\
(\mu \mathrm{m})\end{array}$ & \\
\hline Kidney bean & $16-42$ & $16-60$ & - & \\
Northern bean & $12-40$ & $12-62$ & - & Elliptical, oval \\
Black bean & $8-34$ & $8-55$ & - & Oval, irregular, round \\
Mung bean & $7-20$ & $10-32$ & - & Oval, spherical \\
Smooth pea & - & - & $20-40$ & Oval, irregular, round \\
Wrinkle pea & - & - & $6-80$ & Oval, round \\
Chick pea & - & - & $8-54$ & Oval, spherical \\
Faba bean & $12-24$ & $20-48$ & - & Oval, spherical \\
Lentil & $15-30$ & $10-36$ & - & Oval, round, ellipsoid \\
\hline \hline
\end{tabular}

transfer phenomena occur (Lii et al., 1996). The term gelatinization has become established in connection with starch and refers to irreversible physical changes taking place upon the heating of starch in water involving the loss of molecular order, the melting of crystallites, granular swelling and disruption and starch solubilization (Biliaderis, 1998; Atwell et al., 1988). The degree of gelatinization can be determined qualitatively and quantitatively by physical, chemical and biochemical methods such as loss of birefringence (Liu et al., 2002), increase in viscosity (Wiesenborn et al., 1994), decrease in enthalpy (Steven and Elton, 1971), proton magnetic resonance (Cooke and Gidley, 1992; Gidley and Bociek, 1988, 1985), loss of X-ray diffraction pattern (Collison, 1968a,b), and differential scanning calorimetry (Marshall et al., 1993).

Gelatinization starts at the hilum of the granule and progresses rapidly to the periphery (Singh et al., 2003). It occurs initially in the amorphous regions as opposed to the crystalline regions of the granule, because hydrogen bonding is weaker in the amorphous areas (Singh et al., 2003). Waxy starches swell more than starches having a normal amylose content (Tester and Debon, 2000). Tester and Morrison (1990) stated that the swelling behaviour of starch is primarily a property of its amylopectin content, and amylose acts as both a diluent and an inhibitor of swelling, especially in the presence of lipid. They also reported that maximal swelling might also be related to the molecular weight and the shape of the amylopectin molecules.Juhasz and Salgo (2008) concluded in their work that amylopectin was primarily responsible for uptake of water and associated low viscosities and restricted swelling of most legume starch granules to their high amylose content.

Ghiasi et al. (1982) indicated that starches with high amylopectin content, e.g., waxy starches have higher gelatinization temperatures than those with a higher amylose content because of the increased levels of crystalline structure associated with amylopectin. Because amylopectin plays a major role in starch granule crystallinity, the presence of amylose lowers the melting point of crystalline regions and the energy for initiation of gelatinization (Flipse et al., 1996).

Kreuger et al. (1987) postulated that more energy is needed to initiate melting in the absence of amyloserich amorphous regions. This correlation is clearly seen in Table 6 which is derived from a study of the gelatinization of legume and non-legume starches using 
DSC (Biliaderis et al., 1980), and which indicates that starches with higher amylose contents have more amorphous regions and less crystalline regions, which thus lowers their gelatinization temperatures (Sasaki et al., 2000). Hence, legume starches, which tend to have higher amylose contents, would be expected to have lower gelatinization temperature (Table 6). However, Vandeputte and Delcour (2004) indicated that whether amylopectin chains have a positive or negative influence on gelatinization temperature depends on the way they are packed into the lamellar structure of the starch granules. They also proposed that the short amylopectin chains may destabilize the lamellar structure in several ways. Chang et al. (2006) reported that the higher average chain length of amylopectin or lower proportion of its short chains might contribute to higher gelatinization temperature of starch granules. Tester (1997) has postulated that gelatinization and swelling properties are controlled, in part, by the molecular structure of amylopectin (unit chain length, extent of branching, molecular weight and polydispersity), starch composition (amylose to amylopectin ratio and phosphorus content), and granule architecture (crystalline to amorphous ratio). Amylopectin from cereals has also been shown to retrograde to a less extent than pea, potato and canna amylopectin, which has been attributed to shorter average chain length in the cereal amylopectin (Kalichevsky et al., 1990; Orford et al., 1987).

During DSC analysis of starch, single or double endothermic peaks are obtained depending on the water concentration during starch gelatinization. Starch gelatinization in excess water exhibits a single endothermic transition, whereas, when a starch-water dispersion is heated in the presence of a limited amount of water, two endothermic transitions are observed (Maaruf et al., 2001; Donovan, 1979). In an extensive study carried out by Biliaderis et al. (1980) to investigate the influence of water content on the appearance of these two endotherms with smooth pea, adzuki bean and lentil starches, similar results were obtained for the three legume starches. When the starches were heated at high water concentrations, single endothermic transitions were observed at approximately $64^{\circ} \mathrm{C}, 75^{\circ} \mathrm{C}$ and $56^{\circ} \mathrm{C}$ for smooth pea, adzuki bean and lentil starch, respectively (Table 6). As the ratio of starch to water increased for each of the starches, the second endotherm started to develop at higher temperatures and became predominant at low water contents. This concentration

Table 6. Thermal characteristics and other physico-chemical properties of various starches (Biliaderis et al., 1980)

\begin{tabular}{|c|c|c|c|c|c|c|c|c|c|c|}
\hline $\begin{array}{l}\text { Starch } \\
\text { source }\end{array}$ & $\begin{array}{l}\text { Phos- } \\
\text { phorus } \\
\text { content } \\
(\%)\end{array}$ & $\begin{array}{l}\text { Amylose } \\
\text { content } \\
(\%)\end{array}$ & $\begin{array}{l}\text { Initial } \\
\text { pasting } \\
\text { temp } \\
\left({ }^{\circ} \mathrm{C}\right)\end{array}$ & $\begin{array}{l}\text { Gelatini- } \\
\text { zation } \\
\text { temp } \\
\left({ }^{\circ} \mathrm{C}\right)\end{array}$ & $\begin{array}{l}\text { Starch } \\
\text { conc. for } \\
\text { DSC exp. } \\
(\%, w / w)\end{array}$ & Tp0 & $\mathrm{Tp} 1$ & $\frac{\mathrm{Tp} 2}{{ }^{\circ} \mathrm{C}}$ & $\mathrm{Tm}$ & $\begin{array}{l}\Delta \mathrm{H} \\
\text { (cal/g) }\end{array}$ \\
\hline Adzuki bean & 0.013 & 34.9 & 78 & 83-(85)-89 & 47.7 & 69 & 75 & 89 & 112 & 4.4 \\
\hline Smooth pea & 0.006 & 33.1 & 73 & 65-(67)-69 & 47.5 & 56 & 64 & 87 & 101 & 3.5 \\
\hline Acid-modified, 5.1 & - & 26.8 & - & - & 47.8 & 60 & 73 & 95 & 103 & 2.4 \\
\hline Acid-modified, 9.6 & - & 23.0 & - & - & 47.9 & 60 & 72 & 96 & 109 & 2.2 \\
\hline Garbanzo bean & 0.010 & 34.1 & 75 & 65-(68)-71 & 45.6 & 68 & 72 & 96 & 108 & 3.1 \\
\hline Red kidney bean & 0.016 & 35.0 & 73 & 64-(66)-68 & 46.3 & 61 & 68 & 86 & 100 & 2.6 \\
\hline Lentil & 0.008 & 45.5 & 66 & 58-(59)-61 & 47.5 & 48 & 56 & 80 & 95 & 2.6 \\
\hline Navy bean & 0.011 & 36.0 & 75 & 68-(71)-74 & 46.1 & 59 & 67 & 83 & 99 & 3.5 \\
\hline Mung bean & 0.016 & 34.9 & 73 & 63-(65)-69 & 47.5 & 57 & 65 & 83 & 99 & 3.9 \\
\hline Faba bean & 0.010 & 32.5 & 72 & 61-(63)-66 & 46.6 & 56 & 65 & 83 & 97 & 3.3 \\
\hline Potato, commercial & 0.075 & 20.0 & 51 & 64-(65)-67 & 46.3 & 55 & 60 & 68 & 85 & 4.4 \\
\hline Corn, commercial & 0.019 & 22.6 & 74 & 63-(65)-68 & 46.4 & 60 & 67 & 78 & 89 & $3.3^{\mathrm{b}}$ \\
\hline Corn, lab prepared & 0.012 & 22.4 & 73 & 62-(65)-67 & 47.3 & 53 & 63 & $75^{c}$ & 86 & 2.7 \\
\hline Acid-modified, $6.5^{\mathrm{a}}$ & - & 22.6 & - & - & 47.9 & 54 & 73 & 99 c & 89 & 2.4 \\
\hline High-amylose corn comm. & 0.029 & 50.3 & 96 & 82-(86)-99 & 48.2 & 71 & 82 & 105 & 114 & $4.2^{\mathrm{b}}$ \\
\hline Waxy corn, commercial & 0.002 & 00.0 & 72 & 64-(68)-70 & 47.6 & 64 & 71 & 88 & 97 & $4.0^{\mathrm{b}}$ \\
\hline
\end{tabular}

${ }^{\mathrm{a} N u m b e r s ~ r e p r e s e n t ~ p e r c e n t ~ l i n t n e r i z a t i o n ; ~}{ }^{b}$ For calculation of $\Delta \mathrm{H}$ values only $\mathrm{P}_{1}$ and $\mathrm{P}_{2}$ were used; ${ }^{\mathrm{c}}$ shoulder. 
dependent shift and differences in the melting points of the three legume starches were proposed to be related to various factors, of which the granular organization and its inherent crystallinity are probably the most important (Biliaderis et al., 1980). The authors also identified factors such as differences in the degree of branching among the amylopectins of the starches. The order of increasing degree of branching was adzuki bean $<$ smooth pea $<$ lentil (Biliaderis et al., 1980). The branching is detrimental to crystallization and hence broadens the melting temperature range and lowers the melting temperature, as found in the field of synthetic polymers (Cowie, 1973). One would expect that the higher the degree of branching, the wider the melting temperature range and the less resistant the starch is to gelatinization (Biliaderis et al., 1980).

Ratnayake et al. (2001) studied the gelatinization transition temperatures [ $\mathrm{T}_{0}$ (onset); $\mathrm{T}_{\mathrm{p}}$ (midpoint); $\mathrm{T}_{\mathrm{C}}$ (conclusion)] and the enthalpies of gelatinization $(\Delta \mathrm{H})$ of starches from four cultivars (Carneval, Carrera, Grande and Keoma) of field pea. They reported that the $\mathrm{T}_{\mathrm{o}}, \mathrm{T}_{\mathrm{p}}, \mathrm{Tc}_{\mathrm{c}}$ and $\Delta \mathrm{H} / \Delta \mathrm{P}$ (enthalpy calculated on the basis of amylopectin content) did not vary significantly among the starches. In contrast, they indicated that the gelatinization temperature range $\left(\mathrm{T}_{\mathrm{C}}-\mathrm{T}_{\mathrm{C}}\right)$ followed the order: Grande $\sim$ Keoma $>$ Carneval $>$ Carrera. The To, $\mathrm{T}$, Tc and $\Delta \mathrm{H}$ of the field pea starches were within the range reported for other legume starches (Hoover and Sosulski, 1991).Additionally,Sandhu and Lim (2008) separated starches from pigeon pea,chick pea, field pea,kidney bean and black gram and reported their gelatinization temperature to be in the range of 68.3 to 69.3\%.Abu et al. (2006) also reported gelatinization temperature of cowpea starch to range from $67.0-78.0^{\circ} \mathrm{C}$. Nearly identical nature of the gelatinization transition temperatures and enthalpies indicates that the numbers of double helices (in the amorphous and crystalline domains) that unraveled and melted during gelatinization were nearly similar in the four starches (Ratnayake et al., 2001). However, the gelatinization temperature range $\left(T_{C}-T_{0}\right)$ differed due to differences in the degree of heterogeneity of the starch crystallites within the granules (Ratnayake et al., 2001).

When gelatinized starch cools, the molecules begin to reassociate into an ordered structure, in a process called retrogradation (Orford et al., 1987). During retrogradation, amylose forms double helical associations of 40-70 glucose units (Jane and Robyt, 1984) whereas amylopectin crystallization occurs by association of the outermost short branches (Ring et al., 1987). The extent of reassociation (or retrogradation) depends on the botanical source of the starch (Gudmundsson, 1992; Gudmundsson et al., 1991; Kalichevsky et al., 1990; Roulet et al., 1990; 6.Orford et al., 1987; Gudmundsson and Eliasson, 1989, 1991, 1992, 1993), the fine structure of amylopectin (Ward et al., 1994; Kalichevsky et al., 1990), water content (Gudmundsson, 1994; Zeleznak and Hoseney, 1986; Longton and LeGrys, 1981), storage temperature (Colwel et al., 1969, Mclver et al., 1968), and the presence of lipids and surfactants (Gudmundsson, 1992; Gudmundsson and Eliason, 1990; Eliasson and Ljunger, 1988a,b; Slade and Levine, 1987; Batres and White, 1986; Evans, 1986). A greater amount of amylose has traditionally been linked to a greater retrogradation tendency in starches (Whistler and BeMiller, 1996), but amylopectin and intermediate materials also play an important role in starch retrogradation during refrigerated storage (Yamin et al., 1999). In non-mutant-genotype starches, the amylose is responsible for short changes (Goodfellow and Wilson, 1990). The amylopectin molecule is responsible for longer term rheological and structural changes of starch gels (Gudmundsson, 1994). The roles of amylose and amylopectin depend on the composite nature of the starch gels where swollen gelatinized starch granules are embedded within an amylose-gel matrix (Steeneken, 1989; Russell, 1987; Christianson and Bagley, 1983; Eliasson and Bohlin, 1982; Ring and Stainsby, 1982).

The impacts of retrogradation in starch-based products can be beneficial or, more commonly, undesirable. There is general consensus that starch retrogradation contributes significantly to staling or undesirable firming of bread and other starch products (Del Nobile et al., 2003; Abd karim et al., 2000;Liu and Thompson, 1998a,1998b). Similarly, the vulnerability of legume starch (high amylose content, Table 1) gels to retrogradation and syneresis makes these types of starches unacceptable for products requiring low-temperature storage. In contrast, retrogradation is sometimes promoted to modify the structural, mechanical or organoleptic properties of certain starch-based products, for example; jam, gels, sauce, jelly, gravy, extruded snacks, vermicelli, soup, biscuit, and creamy desserts (Morikawa and Nishinari, 2000; Perera and Hoover, 1999; Yoshimura et al., 1999). Of considerable interest from a food point of view is that retrograded starch is resistant to the action of $\alpha$-amylase in the ileum and is therefore not a source of blood glucose (Crapo et al., 1977) but passes into the colon where it is acted upon 
by gut bacteria (Roder et al., 2005). The retrograded starch shows a B-type X-ray diffraction pattern (Zobel, 1988b). Because starch retrogradation is a kinetically controlled process (Slade and Levine, 1987), the alteration of time, temperature and water content during processing can produce a variety of end products.

Starch retrogradation enthalpies are usually $60-80^{\circ} \mathrm{C}$ lower than gelatinization enthalpies, and transition temperatures are $10-26^{\circ} \mathrm{C}$ lower than those for gelatinization of starch granules (Baker and RayasDuarte, 1998; Yuan et al., 1993;White et al., 1989). The crystalline forms of retrograded starches are different in nature from those present in the native starch granules (Abd Karim et al., 2000). Retrograded starches show lower gelatinization temperatures and enthalpy than native starches because they have weaker starch crystallinity (Sasaki et al., 2000).

Tjahjadi and Breen (1984) reported that the degree of retrogradation, as measured by syneresis of Adzuki bean starch was greater than that of corn, wheat or potato starch gels. The authors also observed that the degree of syneresis decreased with increasing starch concentration. This behavior agreed with the results earlier obtained by Lii and Chang (1981) who reported that this pattern is characteristic of many legume starches. Ratnayake et al. (2001) studied the extent of retrogradation during gel storage and monitored it by determining changes in retrogradation enthalpy and in freeze-thaw stability. They indicated that in four field pea starches, $T_{0}, T_{p}$ and $T_{c}$ of retrograded gels were lower than those for the gelatinization endotherm, and $\mathrm{T}_{\mathrm{C}}-\mathrm{T}_{\mathrm{o}}$ for retrogradation was broader than for the gelatinization endotherm. These authors reported that the magnitude of $\Delta \mathrm{HR}$ (enthalpy of retrogradation) followed the order: Carneval $>$ Carrera $>$ Grande $>$ Keoma, whereas, $T_{c}-T_{0}$ followed the order: Keoma $>$ Grande $>$ Carneval $>$ Carrera. They implied that the wide melting temperature range $\left(\mathrm{T}_{\mathrm{c}}-\mathrm{T}_{\mathrm{o}}\right)$ might be due to a large variation in the quantity and heterogeneity of the recrystallized amylopectin and explained differences in $\Delta \mathrm{H}_{\mathrm{R}}$ among starches on the basis of amylopectin unit chain length distribution (Lai et al., 2000; Fredriksson et al., 1998; Lu et al., 1997; Ward et al., 1994; Shi and Seib, 1992; Kalichevsky et al., 1990).

Generally, legume starches retrograde significantly due to their relatively high amylose contents, although long term retrogradation, which has been blamed for deterioration in the quality of starch-based product, is attributed to short chains of amylopectin (Robin et al., 1974). Amylopectin has high water-binding capacity and slowly undergoes retrogradation, thus forming clear gels that are soft and flow well (Yuan et al., 1993).

Summary and conclusions. Inexpensive legumes are the major sources of dietary proteins, as animal proteins are expensive and beyond the reach of the poor. They are also rich in other nutrients such as starch, dietary fibre, vitamins, oils, phytochemicals and mineral elements.

Greater attention has been given to the protein component of legume seeds, despite the fact that the major component is starch. The protein found in this legumes is rich in lysine yet deficient in sulphur containing amino acids, hence the need to consume the products with cereal products to improve the quality of the protein. However, utilization of the starch fraction will be economically important if the proteins are used as food. Despite the current low production and utilization of legume starches in comparison with cereal starches, the former play important roles in the food industries because they affect the physical properties of many foods and are used as gelling agents, thickners, emulsion stabilizers and water binders. Legume starches differ in granule morphology, gelatinization temperature range and amylose content. They generally exhibit Ctype X-ray patterns (mixture of A- and B- type X-ray patterns). The retrogadation and syneresis associated with legume starches can be reduced by physically or chemically modifying the native starches to make them more acceptable in food and non-food applications.

\section{References}

AACCI, 1984. Approved Methods of the AACC $8^{\text {th }}$ edition. American Association of Cereal Chemists International, St Paul, MN, USA.

Abd Karim, A., Norziah, M.H., Seow, C.C. 2000. Methods for the study of starch retrogradation. Food Chemistry, 711: 9-36.

Abu, J.O., Muller, K., Daodu, K.G., Minnaar, A. 2006. Effect of $\gamma$-irradiation on some physicochemical and thermal properties of cowpea (Vigna unguiculata L. Walp) starch. Food Chemistry, 95: 386-393.

Allen, O.N., Allen, E.K. 1981. The leguminosae, A Source Book of Characteristics, Uses and Modulation. The University of Wisconsin Press, Madison, WI, USA.

Anjum, F.M., Walker, C.E. 1991. Review of the significant 
of starch and protein to wheat hardness. Journal of Science Food and Agriculture, 56: 1-13.

AOACI. 1990. Official Methods of Analysis of the Association of Official Analytical Chemists International, Vol. II, $15^{\text {th }}$ edition, Sec.985.29. The Association: Arlington, VA., USA.

Asaoka, M., Okuno, K., Fuwa, H. 1985. Effect of environmental temperature at the milky state on amylose content and fine structure of waxy and non-waxy endosperm starches of rice (Oryza sativa L.). Agricultural and Biological Chemistry, 49: 373-376.

Atwell, W.A., Hood, L.F., Lineback, D.R., Varriano, M.E., Zobel, H.F. 1988. The terminology and methodology associated with basic starch phenomenon. Cereal Foods World, 33: 306-311.

Badenhuizen, N.P. 1969. The biogenesis of starch granules in higher plants. New York, Appleton Crofts.

Baker, I.A., Rayas-Duarke, P. 1998. Free-thaw stability of amaranth starch and the effects of salt and sugars. Cereal Chemistry, 75: 301-303.

Banks, W.,Greenwood,C.T. 1975. Starch and its Component. pp. 307-309, The University Press, Edinburgh, UK.

Batres, L.V., White, P.J. 1986. Interaction of amylopectin with monoglycerides in model systems. American Oil Chemists Society, 12: 1537-1540.

BeMiller, J.N. 1965. Acid hydrolysis and other lytic reactions of starch. Starch Chemistry, 1: 495.

Betancur-Ancona, D., López-Luna, J., Chel-Guerrero, L. 2003. Comparison of the chemical composition and functional properties of Phaseolus lunatus prime and tailing starches. Food Chemistry, 82: 217-225.

Biliaderis, C.G. 1998. Structure and phase transitions of starch polymers. In: Polysaccharides Association Structures in Food. pp. 57-168, R.H., Walter, (ed.), Marcel Dekker, Inc., New York, USA.

Biliaderis, C.G., Vaughan, D.J. 1987. Electron spin resonance studies of starch-water-probe interactions. Carbohydrate Polymers, 7: 51-70.

Biliaderis, C.G., Maurice, T.J., Vose, J.R. 1981. Structural characterization of legume starches. I. Studies on amylose, amylopectin and $\beta$-limit dextrins. Cereal Chemistry, 58: 496-502.

Biliaderis, C.G., Maurice, T.J., Vose, J.R. 1980. Starch gelatinization phenomena studied by differential scanning calorimetry. Journal of Food Science, 45: $1669-1680$.

Biliaderis, C.G., Grant, D.R., Vose, J.R. 1979. Molecular weight distributions of legume starches by gel chromatography. Cereal Chemistry, 56: 475.

Blanshard, J.M.V. 1987. Starch granule structure and function: a physicochemical approach. In: Starch Properties and Potential, T. Galliard, (ed), pp.1654, Wiley, New York, USA.

Blanshard, J.M.V., Bates, D.R., Muhr, A.H., Worcester, D.L., Higgins, J.S. 1984. Small-angle neutron scattering studies of starch granule structure. Carbohydrate Polymers, 4: 427-442.

Bogracheva, T.Ya., Morris, V.J., Ring, S.G., Hedley, C.L. 1998. The granular structure of C-type pea starch and its role in gelatinization. Biopolymers, 45: 323-332.

Cairns, P., Leloup, V.M., Miles, M.J., Ring, S.G., Morris, V.J. 1990. Resistant starch: an X-ray diffraction study into the effect of enzymatic hydrolysis on amylose gels in-vitro. Journal of Cereal Science, 12: 203-206.

Cameron, R.E., Donald, A.M. 1992. A small-angle X-ray scattering study of the annealing and gelatinization of starch. Polymer, 33: 2628-2635.

Chang, Y.-H., Lin, C.-L., Chen, J.-C. 2006. Characteristics of mung bean starch isolated by using lactic acid fermentation solution as the steeping liquor. Food Chemistry, 99: 794-802.

Chavan, U.D., Shinde, B.G., Kadam, S.S., Amarowicz, R. 2010. Isolation and characterization of starch from horse gram. African Journal of Food Science and Technology, 1: 64-67.

Chavan, U.D., Momin, A., Chavan, J.K., Amarowicz, R. 2009. Characteristics of starch from rice bean (Vigna umbellata L.) seeds. Polish Journal of Food and Nutrition Sciences, 59: 25-27.

Chavan, U.D., Shahidi, F., Hoover, R., Perera, C. 1999. Characterization of beach pea (Lathyrus maritimus L.) starch. Food Chemistry, 82: 217-225.

Cheetham, N.W.H., Tao, L. 1997. The effects of amylose content on the molecular size of amylose, and on the distribution of amylopectin chain length in maize starches. Carbohydrate Polymers, 35: 251-261.

Christianson, D.D., Bagley, E.B. 1983. Apparent viscosity of dispersions of swollen corn starch granules. Cereal Chemistry, 60: 116-121.

Chung, H.L., Liu, Q., Hoover, R. 2009. Impact of annealing and heat-moisture treatment on rapidly digestible, slowly digestible and resistant starch levels in native and gelatinized corn, pea and lentil starches. Carbohydrate Polymers, 75: 436-447.

Chung, H.J., Liu, Q., Hoover, R., Warkentin, T.D., Vandenberg, B. 2008a. In vitro starch digestibility, 
expected glycemic index, and thermal and pasting properties of flours from pea, lentil and chickpea cultivars. Food Chemistry, 111: 316-321.

Chung, H.J., Liu, Q., Pauls, K.P., Fan, M.Z., Yada, R. 2008b. In vitro starch digestibility, expected glycemic index and some physicochemical properties of starch and flour from common bean (Phaseolus vulgaris L.) varieties grown in Canada. Food Research International, 41: 869-875.

Clemente, A., Vioque, J., Sanchez Vinque, R., Pedroche, J., Bautista, J., Millan, F. 2000. Factors affecting the in vitro protein digestibility of chickpea albumins. Journal of the Science of Food and Agriculture, 80: 79-84.

Collison, R. 1968a. Starch retrogradation. In: Starch and its Derivatives. J. A. Radley, (ed.), Chapman and Hall, Ltd., London, UK.

Collison, R. 1968b. Swelling and gelation of starch. In: Starch and its Derivatives. J. A. Radley, (ed.) pp. 168-193, Chapman and Hall, London, UK.

Colonna, P., Buleon, A., Lemaguer, M., Mercier, C. 1982. Pisum sativum and Vicia fuba carbohydrates: Part IV - Granular structure of wrinkled pea starch. Carbohydrate Polymers, 2: 43-59.

Colonna, P., Buleon, A., Mercier, C. 1981. Pisum sativum and Vicia fuba carbohydrates: structural studies of starches. Journal of Food Science, 46: 88-93.

Colwell, K.H., Axford, D.W.E., Chamberlain, N., Elton, G.S.H. 1969. Effect of storage temperature on the ageing of concentrated wheat starch gels. Journal of the Science Food and of Agriculture, 20: 550-555.

Cooke, D., Gidley, M.J. 1992. Loss of crystalline and molecular order during starch gelatinization: origin of the enthalpic transition. Carbohydrate Research, 227: 103-112.

Cowie, J.M.C. 1973. Polymers: Chemistry and Physics of Modern Materials. Intertext Books.

Crapo, P.A., Reaven, G., Olefsky, J. 1977. Post-prandial plasma-glucose and insulin responses to different complex carbohydrates. Diabetes, 26: 1178-1183.

Czuchajowska, Z., Otto, T., Paszczynska, B., Baik, B. 1998. Composition, thermal behavior, and gel texture of prime and tailing starches from garbanzo beans and peas. Cereal Chemistry, 75: 466-472.

Davydova, N.I., Leont'ev, S.P., Genin, Ya.V., Sasov, A.Yu., Bogracheva, T.Ya.1995. Some physicochemical properties of smooth pea starches. Carbohydrate Polymers, 27: 109-115.

Del Nobile, M.N., Martoriello, T., Mocci, G., La Notte, E. 2003. Modeling the starch retrogradation kinetic of durum wheat bread. Journal of Food
Engineering, 59: 123-128.

Deshpande, S.S., Damodaran, S.S. 1990. Food legumes: chemistry and technology. In: Advances in Cereal Science and Technology. Vol. 10, pp. 147-241. American Association of Cereal Chemists, St. Paul, MN, USA.

Destefanis, V.A., Ponte, J.G., Jr, Chung, F.H., Ruzza, N.A. 1977. Binding of crumb softeners and dough strengtheners during breadmaking. Cereal Chemistry, 54: 13-24.

Donovan, J.W. 1979. Phase transitions of starch/water systems. Biopolymers, 18: 263-275.

Duke, J.A. 1981. Handbook of Legumes of World Economic Importance, pp 39-42, Plenum Press: New York and London.

Eliasson, A.C., Ljunger, G. 1988a. Effects of added inclusion-amylose complex on the retrogradation of some starches and amylopectin. Carbohydrate Polymers, 17: 299-304.

Eliasson, A.C., Ljunger, G. 1988b. Interactions between amylopectin and lipid additives during retrogradation in a model system. Journal of the Science of Food and Agriculture 44: 353-361.

Eliasson, A.C., Bohlin, L. 1982. Rheological properties of concentrated wheat starch gels. Starch, 34: 231235.

Ellis, R.P., Cochrane, M.P., Dale, M.F.B., Duffus, M.C., Lynn, A., Morrison, I.M., Prentice, R.D.M., Swanston, J.S., Tiller, S.A. 1998. Starch production and industrial use. Journal of the Science of Food and Agriculture, 77: 289-311.

Evans, I.D. 1986. An investigation of starch/surfactant interactions using viscometry and differential scanning calorimetry. Starch, 34: 224-231.

Fannon, J.E., BeMiller, J.N. 1992. Structure of corn starch paste and granule remnants revealed by low temperature scanning electron microscopy after cryopreparation. Cereal chemistry, 69: 456-460.

Fannon, J. E., Hauber, R. J., BeMiller, J. N. 1992a. Surface pores of starch granules. Cereal Chemistry, 69: 284-288.

Fannon, J.E., Hauber, R.J., BeMiller, J.N. 1990. Use of low temperature scanning electron microscopy to examine starch granule structure and behavior, In: Frontiers in Carbohydrate Research, R. Chandrasekran (ed.), vol. 2, pp. 1-23, Elsevier Science Publ., Amsterdam, The Netherlands. FAO, 2003. Report on Agriculture towards 2015/2030.

Fitt, L.E.,Snyder,E.M. 1984. Photomicrographs of Starches, In: Starch Chemistry and Technology, (R. L. Whistler, J. N. BeMiller, E. G. Paschall, 
(eds.) $2^{\text {nd }}$ edition, pp. 675-689, Academic Press, New York, USA.

Flipse, E., Keetels, C.J.A.M., Jacobson, E., Visser, R. G.F. 1996. The dosage effect of the wildtype GBSS allele is linear for GBSS activity, but not for amylose content: absence of amylose has a distinct influence on thew physicochemical properties of starch. Theoretical and Applied Genetics, 92: 121-127.

Fredriksson, H., Silverio, J., Andersson, R., Eliasson, A.C., Aman, P. 1998. The influence of amylose and amylopectin characteristics on gelatinization and retrogradation properties of different starches. Carbohydrate polymers, 35: 119-134.

Galliard, T., Bowler, P. 1987. Morphology and composition of starch. In: Starch Properties and Potential, vol., 13, pp. 55-78, T. Galliard, (ed.). John Willey, New York, USA.

Gernat, C., Radosta, S., Anger, H., Damaschun, G. 1993. Crystalline parts of three different conformations detected in native and enzymatically degraded starches. Starch, 45: 309-314.

Gernat, C., Radosta, S., Damaschun, G., Schierbaum, F. 1990. Supermolecular structure of legume starches revealed by X-ray scattering. Starch, 42: 175-178.

Ghiasi, K., Hoseney, R.C., Varriano-Marston, E. 1982. Gelatinization of wheat starch. I. Excess-water systems. Cereal Chemistry, 59: 258-262.

Gidley, M.J., Bociek, S.M. $1988 .{ }^{13} \mathrm{C}$ CP/MAS NMR studies of amylose inclusion complexes, cyclodextrins, and the amorphous phase of starch granules: Relationships between glycosidic linkage conformation and solid state ${ }^{13} \mathrm{C}$ chemical shifts. Journal of American Chemical Society, 110: 3820-3829.

Gidley, M.J., Bociek, S.M. 1985. Molecular organization in starches: A ${ }^{13} \mathrm{C} C P /$ MAS NMR study. Journal of the American Chemical Society, 107: 7040-7044.

Goering, K.J., Jackson, L.L., Dehaas, B.W. 1975. Effect of some non-starch components in corn and barley starch granules on the viscosity of heated starchwater suspensions. Cereal Chemistry, 52: 493-500.

Goodfellow, B.J., Wilson, R.H. 1990. A Fourier transform IR study of the gelatinization of amylose and amylopectin. Biopolymer, 30: 1183-1189.

Goshima, G., Abe, M., Sato, N., Ohashi, K., Tsuge, H. 1985. Amylographic reproducibility of defatted potato starch by the reintroduction of lipid. Starch, 37: 10-14.

Gudmundsson, M. 1994. Retrogradation of starch and the role of its components. Thermochimica Acta, 246: 329-341.
Gudmundsson, M., Eliansson, A.C. 1993. Comparison of thermal and viscoelastic properties of four waxy starches and the effect of added surfactant. Starch, 45: 379-385.

Gudmundsson, M. 1992. Cereal Starches: Physicochemical Properties and Retrogradation, Thesis, Lund University, Sweden.

Gudmundsson, M., Eliansson, A.C. 1992. Some physical properties of barley starches from varieties differing in amylose content. Journal of Cereal Science, 16: 95-105.

Gudmundsson, M., Eliansson, A.C. 1991. Thermal and viscous properties of rye starch extracted from different varieties. Cereal Chemistry, 68: 172-177.

Gudmundsson, M., Eliansson, A.C., Bengtsson, S., Aman, P. 1991. The effects of water soluble arabinoxylan on gelatinization and retrogradation of starch. Starch, 43: 5-10.

Gudmundsson, M., Eliansson, A.C. 1990. Retrogradation of amylopectin and the effects of amylose and added surfactants/emulsifiers. Carbohydrate Polymers, 13: 295-315.

Gudmundsson, M., Eliansson, A.C. 1989. Some physicochemical properties of oat starches extracted from varieties with different oil content. Acta Agriculture Scandinavia, 39: 101-112.

Hahn, D.E., Hood, L.F. 1987. Factors influencing corn starch-lipid complexing. Cereal Chemistry, 64: 81-85.

Hargin, K.D., Morrison, W.R. 1980. The distribution of acyl lipids in the germ, aleurone, starch and nonstarch endosperm of four wheat varieties. Journal of the Science of Food and Agriculture, 31: 877-888.

Hizukuri, S. 1969. The effect of environmental temperature of plant on the physicochemical properties of their starches. Journal of Japanese Society of Starch Science, 17: 73-88.

Hoover, R., Ratnayake, W.S. 2002. Starch characteristics of black bean, chickpea, lentil, navy bean and pinto bean cultivars grown in Canada. Food Chemistry, 78: 489-498.

Hoover, R. 2001. Composition, molecular structure, and physico-chemical properties of tuber and root starches: a review. Carbohydrate Polymers, 45: 253-267.

Hoover, R., Li, Y.X., Hynes, G., Senanayake, N. 1997. Physicochemical characterization of mung bean starch. Food Hydrocolloids, 11: 401-408.

Hoover, R., Manuel, H. 1996. Effect of heat-moisture treatment on the structure and physicochemical properties of legume starches. Food Research International, 29: 731-750. 
Hoover, R., Manuel, H. 1995. A comparative study of the physicochemical properties of starches from two lentil cultivars. Food Chemistry, 53: 275-284.

Hoover, R., Sosulski, F. 1991. Composition, structure, functionality, and chemical modification of legume starches: a review. Canadian Journal of Physiology and Pharmacology, 69: 79-92.

Hoover, R., Hanncuz, D., Solsulski, F.W. 1988. Effect of hydroxypropylation on thermal properties, starch digestibility and freeze thaw stability of field pea (Pisum sativum cv Trapper) starch. Starch, 40: 383-387.9.

Hoover, R., Sosulski, F.W. 1986. Effect of cross-linking on fanctional properties of legume starches. Starch, 38: $149-155$.

Hoover, R., Sosulski, F.W. 1985. Studies on the functional characteristics and digestibility of starches from Phaseolus vulgaris biotypes. Starch, 37: 181-191.

Hsu, S., Lu, S., Huang, C. 2000. Visco-elastic changes in rice starch suspensions during gelatinization. Journal of Food Science, 65: 215-220.

Hughes, T., Hoover, R., Liu, Q, Donner, E., Chibbar, R., Jaiswal, S. 2009. Composition, morphology, molecular structure, and physicochemical properties of starches from newly released chickpea (Cicer arietinum L.) cultivars grown in Canada. Food Research International, 42: 627-635.

Inatsu, O., Watanabe, K., Maidu, I., Ito, K, Osani, S.J. 1974. Studies to improve the quality of rice grown in Hokkaido.I. Amylose contents of different rice starches. Journal of Japan Society of Starch Science, 21: $115-117$.

Jacobs, H., Delcour, J.A. 1998. Hydrothermal modifications of granular starch with retention of the Granular structure: A review. Food Chemistry, 46: 2895-2905.

Jane, J., Kasemsuwun, T., Leas, S., Zobel, H.F., Robyt, J. F. 1994. Anthology of starch granule morphology by scanning electron microscopy. Starch, 46: 121-129.

Jane, J.L., Robyt, J.F. 1984. Structural studies of amylose $\mathrm{V}$ complexes and retrograded amylose by action of alpha amylase, a new method for preparing amylodextrins. Carbohydrate Research, 132: 105-110.

Jenkins, P.J., Donald, A.M. 1995. The influence of amylose on starch granule structure. International Journal of Biological Macromolecules, 17: 315-321.

Jenkins, P.J.1994. X-ray and Neutron Scattering Studies on Starch Granule Structure. Ph.D.Thesis, University of Cambridge, UK.

Jenkins, P.J., Cameron, R.E., Donald, A.M. 1993. A universal feature in the structure of starch granules from different botanical sources. Starch, 45: 417-420.

Juhasz, R., Salgo, A. 2008. A pasting behaviour of amylose, amylopectin and their mixtures as determined by RVA curves and first derivatives. Starch, 60: 70-78.

Juliano, B.O., Bautista, G.M., Lugay, J.C., Reyes, A.C.J. 1964. Studies on the physicochemical properties of rice. Journal of Agricultural and Food Chemistry, 12: 131-134.

Kainuma, K., French, D. 1971. Nageli amylodextrin and its relationship to starch granule structure. I. Preparation and properties of amylodextrins from various starch types. Biopolymers, 10: 1673-1680.

Kalichevsky, M.T., Orford, P.D., Ring, S.G. 1990. The retrogradation and gelation of amylopectins from various botanical sources. Carbohydrate Resarch, 198: 49-55.

Kassenbeck, P. 1978. Beitrag zur kenntnis der Verteilung von Amylose und Amylopectin in Starchkörnern. Starch, 30: 40-46.

Kaur, L., Singh, N., Sodhi, N.S. 2002. Some properties of potatoes and their starches. II. Morphological, thermal and rheological properties of starches. Food Chemistry, 79: 183-192.

Kawano, M., Mura, K., Tanimura, W. 1989. Effect of embraced fatty acids and penetrated fatty acids on photopastegrams of starch. Journal of Agriculture Science, 33:191-197.

Kessler, M. 1985. Canavalia ensiformis. Introducciôn a la Planta y Comportamiento Agronómico en Yucután. Memories of la Reunion sobre Producción y htilizacion del Grano de Canavalia ensiformis en Sistemas Peuiarios de Yucatán; Facultad de Medicina Veteranaria y Zootechnia, Universidicd Autonoma de Yucatán. Yucatán, Méxìco, pp 1-15.

Kevate,B.N., Chavan, U.D., Kadam, S.S., Chavan,J.K., Amarowicz,R. 2010. Isolation and characterization of starch from moth bean. African Journal of Food Science and Technology, 13: 68-70.

Kim, S.H., Lee, B.-H., Baik, M.-Y., Joo, M.-H.,Yoo, S.-H. 2007. Chemical structure and physical properties of mung bean starches isolated from 5 domestic cultivars. Journal of Food Science, 72: 471-477.

Kim, S.Y., Wiensenborn, D.P., Orr, P.H., Grant, L.A. 1995. Screening potato starch for novel properties using differential scanning calorimetry. Journal of Food Science, 60: 1060-1065.

Kreuger, B.R., Knatson, C.A., Inglett, G.E., Walker, C.E. 1987. A differential scanning calorimetry 
study on the effect of annealing on gelatinization behavior of corn starch. Journal of Food Science, 52: 715-718.

Krog, N. 1971. Amylose complexing effect of food grade emulsifiers. Starch, 23: 206-210.

Krossmann, J., Lloyd, J. 2000. Understanding and influencing starch biochemistry. Critical Reviews in Biochemistry and Molecular Biology, 35: 141-196.

Lagendijk, J., Pennings, H.J. 1970. Relation between complex formation of starch with monoglycerides and the firmness of bread. Cereal Science Today, 15: 354-365.

Lai, V.M.F., Lu, S., Lii, C.Y. 2000. Molecular characteristics influencing retrogradation kinetics of rice amylopectins. Cereal Chemistry, 77: 272-278.

Leach, H.W., McCowen, L.D., Schoch, T.J. 1959. Structure of the starch granule. I. Swelling and solubility patterns of various starches. Cereal Chemistry, 36: 534-544.

Lee, H.C., Htoon, A.K., Paterson, J.L. 2007. Alkaline extraction of starch from Australian lentil cultivars Matilda and Digger optimized for starch yield, starch and protein quality. Food Chemistry, 102: 551-559.

Lelievre, J. 1973. Starch gelatinization. Journal of Applied Sciences, 18: 293.

León, A.I., Michelangeli, C., Vargas, R.E., Carballo, J.M., Risso, J., Montilla, J.J. 1991. Valor Nutricional de los Granos de Canavalia ensiformis en Dietas para Aves y Cerdos. Memories of the Seminario Taller sobre Canavalia ensiformis; Maracay, Venezuela.

León, A.I., Angulo, M., Picard, B., Carré, L., Derouet, H., Harscoat, J. P.1989. Proximate and Amino Acid Composition of Seed of Canavalia ensiformis. Toxicity of the Kernel Fractions for Chicks. Annnalesd Zootechnol, 38: 209-213.

Li, S.-L., Gao, Q.-Y. 2010. Effect of heat moisture treatment on the formation and properties of resistant starches from mung bean (Phaseolus radiatus) starches. World Academy of Science, Engineering and Technology, 72: 812-819.

Lii, C.Y., Tsai, M.L., Tseng, K.H. 1996. Effect of amylose content on the rheological property of rice starch. Cereal Chemistry, 73: 415-420.

Lii, C.Y., Chang, S.M. 1981. Characterization of red bean (Phaseolus radiates var. aurea) starch and its noodle quality. Journal of Food Science, 46: 78-81.

Lineback, D.R., Ke, C. H. 1975. Starches and low molecular weight carbohydrates from chick pea and horsebean flours. Cereal Chemistry, 52: 334.
Liu, Q., Charlek, G., Yelle, S., Arul, J. 2002. A study of phase transition in the starch-water system. I. Starch gelatinization at high moisture level. Food Research International, 35: 397-407.

Liu, Q., Thompson, D.B. 1998a. Effects of moisture content and different gelatinization heating temperatures on retrogradation of waxy-type maize starches. Carbohydrate Research, 314: 221-235.

Liu, Q., Thompson, D.B. 1998b. Retrogradation of du wx and su2 wx maize starches after different gelatinization heat treatments. Cereal Chemistry, 75: 868-874.

Liu, W.-J., Shen, Q. 2007. Studies on the physicochemical properties of mung bean starch from sour liquid processing and centrifugation. Journal of Food Engineering, 79: 358-363.

Longton, J., LeGrys, G.A. 1981. Differential scanning calorimetry studies on the crystallinity of ageing wheat starch gels. Starch, 33: 410-414.

Lorenz, K. 1976. Physicochemical properties of lipidfree cereal starches. Journal of Food Science, 41: 1357-1359.

Lu, S., Chem, L.N., Lii, C. Y. 1997. Correlations between the fine structure, physicochemical properties, and retrogradation of amylopectins from Taiwan rice varieties. Cereal Chemistry, 74: 34-39.

Maaruf, A.G., Che Man, Y.B., Asbi, B.A., Junainah, A. H., Kennedy, J.F. 2001. Effect of water content on the gelatinization temperature of sago starch. Carbohydrate Polymer, 46: 331-337.

Madsen, M.H., Christensen, D.H. 1996. Changes in viscosity properties of potato starch during growth. Starch, 48: 245-249.

Maningat, C.C., Juliano, B.O. 1980. Starch lipids and their effect on rice starch properties. Starch, 32: 76-82.

Manners, D.J. 1974. The structure and metabolism of starch. In: Essays in Biochemistry, P. N. Cambell, F. Dickens, (eds.), 37, pp. Academic Press, New York, USA.

Marchant, J.L., Blanshard, J.M.V. 1978. Studies on the dynamics of the gelatinization of starch granules employing a small angle light scattering system. Starch, 30: 257.

Marshall, W.E., Wadsworth, J.I., Verma, L.R., Velupillai, L. 1993. Determining the degree of gelatinization in parboiled rice: Comparison of a subjective and an objective method. Cereal Chemistry, 70: 226-230.

McCrone, W.C.,Delly,J.G. 1973. The particle Atlas, vol. 2, pp. 173-326, $2^{\text {nd }}$ edition, Ann Arbor Science Publ., Ann Arbor, MI, USA.

Mclver, R.G., Axford, D.W.E., Colwell, K.H., Elton, 
G.A.H. 1968. Kinetic study of the retrogradation of gelatinized starch. Journal of Science of Food and Agriculture, 19: 560-563.

Medcalf, D.G., Youngs, V.L., Gilles, K.A. 1968. Wheat starches. II. Effect of polar and non-polar lipid fractions on pasting characteristics. Cereal Chemistry, 45: 88-95.

Melvin, M.A. 1979. The effect of extractable lipid on the viscosity characteristics of corn and wheat starches. Journal of the Science of Food and Agriculture, 30: 731-738.

Menkov, H.D. 2000. Moisture sorption isotherms of chickpea seeds at several temperatures. Journal of Food Engineering, 45: 189-194.

Miao, M., Zhang, T., Jiang, B. 2009. Characterization of kabuli and desi chickpea starches cultivated in China. Food Chemistry, 113: 1025-1032.

Mikus, F.F., Hixon, R.M., Rundle, R.E. 1946. The complexes of fatty acids with amylose. Journal of America Science Society, 68: 1115-1123.

Morikawa, K., Nishinari, K. 2000. Effects of concentration dependence of retrogradation behavior of dispersions for native and chemically modified potato starch. Food Hydrocolloids, 14: 395-401.

Morrison, W.R., Law, R.V., Snape, C.E. 1993. Evidence for inclusion complexes of lipids with V-amylose in maize, rice and oat starches. Journal of Cereal Science, 18: 107-109.

Morrison, W.R., Tester, R.F., Gidley, M.J., Karkalas, J. 1993a. Resistant to acid hydrolysis of lipid complexed and lipid-free amylose in lintnerised waxy and non-waxy barley starch. Carbohydrate Research, 245: 289-302.

Morrison, W.R., Tester, R.F., Snape, C.E., Law, R., Gidley, M.J. 1993b. Swelling and gelatinization of cereal starches. IV. Some effects of lipid-complexed amylose and free amylose in waxy and normal barley starches. Cereal Chemistry, 70: 385-391.

Morrison, W.R., Azudin, M.N. 1987. Variation in the amylose and lipid contents and some physical properties of rice starches. Journal of Cereal Science, 5: 35-37.

Morrison, W.R., Coventry, A.M. 1985. Extraction of lipids from cereal starches with hot aqueous alcohols. Starch, 37: 83-87.

Morrison, W.R., Milligan, T.P., Azudin, M.N. 1984. A relationship between the amylose and lipids contents of starches from diploid cereals. Journal of Cereal Science, 2: 257-260.

Morrison, W,R. 1981. Starch lipids: A reappraisal. Starch, 33: 408-410.
Muhr, A.H., Blanshard, J.M.V., Bales, D.R. 1984. The effect of lintnerisation on wheat and potato starch granules. Carbohydrate Polymers, 4: 399-425.

Naivikul, O., D’Appolonia, B.L. 1979. Carbohydrates of legume flours compared with wheat flour, 2, starch. Cereal Chemistry, 56: 24.

Nishinari, K. 2008. Structure and viscoelastic properties of starches separated from different legumes. Starch, 60: 349-357.

Oostergetel, G.T., Van Bruggen, E.F.J. 1989. On the origin of a low angle spacing in starch. Starch, 41: 331-335.

Orford, P.D., Ring, S.G., Carroll, V., Miles, M.J., Morris, V.J. 1987. The effect of concentration and botanical source on the gelatinization and retrogradation of starch. Journal of the Science of Food and Agriculture, 39: 169-173.

Perera, C., Hoover, R. 1999. Influence of hydroxypropylation on retrogradation properties of native, deffated and heat-moisture treated potato starches. Food Chemistry, 64: 361-375.

Polesi, L.F., Sarmento, S.B.S., Des Anjos, C.B.P. 2011. Composition and characterization of pea and chickpea starches. Brazil Journal of Food Technology Campinas, 14: 74-81.

Ratnayake, W.S., Hoover, R., Warkentin, T. 2002. Pea starch: composition, structure, and properties. A review. Starch, 54: 217-234.

Ratnayake, W.S., Hoover, R., Shahidi, F., Perera, C., Jane, J. 2001. Composition, molecular structure, and physicochemical properties of starches from four field pea (Pisum sativum L.). Food Chemistry, 74: 189-202.

Reichert, E.T. 1913. The Differentiation and specificity of starches in relation to genera, species, development, and evolution. Carnegie Institute Washington Publication, 173: 777-890.

Ring, S.G., Collona, P., Panson, K.J., Kalicheversky, M.T., Miles, M.J., Morris, V.J. 1987. The gelation and crystallization of amylopectin. Carbohydrate Research, 162: 277-293.

Ring, S.G., Stainsby, G.R. 1982. Filler reinforcement of gels. Progress in Food Nutrition Science, 6: 323-329.

Robin, J.P., Mercier, C., Duprat, F., Charbonniere, R., Guilbolt, A. 1975. Amidons lintnerises. Etudes chromatographique et enzymatique des chlorhydrique d' amidons de cereals, en particulier de mais cireux. Starch, 27: 36.

Robin, J.P., Mercier, C., Charbonniere, R., Guilbolt, A. 1974. Lintnerized starches, gel filtration and enzymatic studies of insoluble residues from 
prolonged acid treatment of potato starch. Cereal Chemistry, 51: 389-406.

Roder, N., Ellis, P.R., Butterworth, P.J. 2005. Starch molecular and nutritional properties. International Journal of Molecular Biology, Biochemistry and Gene Technology, 1: 5-14.

Roulet, P., Macinnes, W.M., Gumy, D., Mursch, P. 1990. Retrogradation kinetics of eight starches. Starch, 42: 99-101.

Russell, P. 1987. The ageing of gels from starches of different amylose/amylopectin content studied by DSC. Journal of Cereal Science, 6: 147-158.

Sandhu, K.S., Lim, S.-T. 2008. Digestibility of legume starches as influenced by their physical and structural properties. Carbohydrate Polymers, 71: 245-252.

Sasaki, T., Yasui, T., Matsuki, J. 2000. Effects of amylose content on gelatinization, retrogradation and pasting properties of starches from waxy and non-waxy wheat and their F1 seeds. Cereal Chemistry, 77: 58-63.

Sathe, S.K. Salunkhe, D.K. 1981. Isolation, Partial Characterization and Modification of the Great Northern Bean (Phaseolus vulgaris L.) Starch Journal of Food Science, 46: 617-621.

Schoch, T.J., Maywald E.C. 1968. Preparation and properties of various legume starches. Cereal Chemistry, 45: 564-573.

Schoch, T.J., Maywald, E.C. 1967. Industrial Microscopy of Starch. In: Starch Chemistry and Technology, R. L. Whistler, E. G. Paschall, J. N. BeMiller, H. J. Roberts. (eds.), vol. 2, pp. 637-685, Academic Press, New York, USA.

Shi, Y.C., Seib, P.A. 1992. The structure of four waxy starches related to gelatinization and retrogradation. Carbohydrate Research, 227: 131-145.

Shibanuma, K., Takeda, Y., Hizukuri, S., Shibaka, S. 1994. Molecular structures of some wheat starches. Carbohydrate Polymers, 25: 111-116.

Singh, J., Singh, N. 2001. Studies on the morphological, thermal and rheological properties of starch separated from some Indian potato cultivars. Food Chemistry, 75: 67-77.

Singh, N., Nakaura, Y., Inouchi, N., Nishinari, K. 2008. Structural and viscoelastic properties of starches separated from different legumes. Starch, 60: 349-357.

Singh, N., Kaur, M., Sandhu, K.S., Guraya, H.S. 2004. Physicochemical, thermal, morphological and pasting properties of starches from some Indian Black gram (Phaseolus mungo L.) cultivars. Starch, 56: 535-544.

Singh, N., Sandhu, K.S., Kaur, M. 2004. Characterization of starches separated from Indian Chickpea (Cicer arietinium L.) cultivars. Journal of Food Engineering, 63: 441-449.

Singh, N., Singh, J., Kaur, L., Sodhi, N.S., Gill, B.S. 2003. Morphological, thermal and rheological properties of starches from different botanical sources. Food Chemistry, 81: 219-231.

Slade, L., Levine, H. 1987. Recent advances in starch retrogradation, In: Industrial Polysaccharides: The Impact of Biotechnology and Advanced Methodologies, S. S. Stivala, V. Crescenzi \& I. C. M. Dea (eds.), pp. 387-430, Gordon and Breach Science Publishers, New York, USA.

Sodhi, N.S., Chang, Y.-H., Kaur, N., Kohyama, K. 2009. Effect of acid-methanol treatment on the molecular structure and physicochemical properties of lentil (Lens culinaris Medik) starch. Food Hydrocolloids, 23: 2219-2225.

Steeneken, P.A.M. 1989. Rheological properties of aqueous suspensions of swollen starch granules. Carbohydrate Polymers, 11: 23-42.

Sterling, C.A. 1962. A low angle spacing in starch. Journal of Polymer Science, 56: 10-12.

Stevens, D.J., Elton, G.A.H. 1971. Thermal properties of starch/water system. I. Measurement of heat of gelatinization by differential scanning calorimetry. Starch, 23: 8-11.

Svegmark, K.K., Hermansson, A.M. 1993. Microstructure and rheological properties of composites of potato starch granules and amylose: a comparison of observed and predicted structure. Food Structure, 12: 181-193.

Takeda, Y., Muruta, N., Hizukuri, S. 1992. Examination of the structure of amylose by tritium labeling of the reduced terminal. Carbohydrate Research, 227: 113-120.

Tan, H.-Z., Li, Z.-G., Tan, B. 2009. Starch noodles: History, classification, materials, processing, structure, nutrition, quality evaluating and improving. Food Research International, 42: 551-576.

Tan, H.-Z., Tan, B., Gao, H., Gu, W.-Y. 2007. Rheological behavior of mung bean starch dough. Food Science and Technology Research, 13: 103-110.

Tan, H.-Z., Gu, W.-Y., Zhou, J.-P., Wu, W.-G., Xie, Y.L. 2006. Comparative study on the starch noodle, structure of sweet potato and mung bean. Journal of Food Science, 71: 447-455.

Tester, R.F., Debon, S.J.J. 2000. Annealing of starch (a review). International Journal of Biological Macromolecules, 27: 1-12.

Tester, R.F., Debon, S.J.J., Sommer-ville, M.D. 2000. Annealing of maize starch. Carbohydrate Polymers, 
42: 287-299.

Tester, R.F. 1997. Starch: the polysaccharide fractions. In: Starch, Structure and Functionality, P. J. Frazier, P. Richmond, and A. M. Donald. (eds.)., pp. 163-171. Royal Society of Chemistry, London, UK.

Tester, R.F., Morrison, W.R., Schuiman, A.R. 1993. Swelling and gelatinization of cereal starches. V. Riso mutants of Bomi and Carlsberg II barley cltivars. Journal of Cereal Science, 17: 1-9.

Tester, R.F., Morrison, W.R. 1990. Swelling and gelatinization of cereal starches. I. Effects of amylopectin, amylose and lipids. Cereal Chemistry, 67: 337.

Thao, H.M., Noomhorm, A. 2011. Physicochemical properties of sweet potato and mung bean starch and their blends for noodle production. Journal of Food Processing and Technology, 2: 105 . doi : 10.4172/2157-7110.1000105.

Tjahjadi, C., Breene, W.M. 1984. Isolation and characterization of adzuki been (Vigna angularis av Takera) starch. Journal of Food Science, 49: 558-565.

Tolmasquim, E., Correa, A.M.N., Tolmasquim, S.T. 1971. New starches. Properties of five varieties of cowpea starch. Cereal Chemistry, 48: 132-139.

Tsai, M.L., Li, C.F., Lii, C.Y. 1997. Effects of granular structure on the pasting behavior of starches. Cereal Chemistry, 74: 750-757.

Vandeputte, G.E., Delcour, J.A. 2004. From sucrose to starch granule to starch physical behavior: a focus on rice starch. Carbohydrate Polymers, 58: 245-266.

Vasanthan, T., Hoover, R. 1992. A comparative study of the composition of lipids associated with starch granules from various botanical sources. Food Chemistry, 43: 19-29.

Vose, J.R. 1977. Functional characteristics of an intermediate amylose starch from smooth seeded field peas compared with corn and wheat starches. Cereal Chemistry, 54: 1140-1151.

Wang, N., Daun, J.K. 2006. Effect of variety and crude protein content on nutrients and anti-nutients in lentil (Lens culinaris). Food Chemistry, 95: 493-502.

Ward, K.E.J., Hoseney, R.C., Seibi, P.A. 1994. Retrogradation of amylopectin from maize and wheat starches. Cereal Chemistry, 71: 150-155.

Watson, S.A. 1964. Determination of starch gelatinization temperature. In: Methods in Carbohydrate Chemistry,
R. L. Whistler (eds.), vol. 4, pp. 240-242, New York: Academic Press, USA.

Whistler, R.L., BeMiller, J.N. 1996. Starch. In: Carbohydrate Chemistry for Food Scientists. R. L. Whistler and J. N. BeMiller (eds.), pp. 177-151,. St. Paul, MN, Eagan Press, USA.

White, P.J., Abbas, I.R., Johnson, L.J. 1989. Free-thaw stability and refrigerated-storage retrogradation of starches. Starch, 41: 176-180.

Wiesenborn, D.P., Orr, P.H., Casper, H.H., Tacke, B.K. 1994. Potato starch paste behaviour as related to some physical/chemical properties. Journal of Food Science, 59: 644-648.

Wu, H.C.H., Sarko, A. 1978. The double-helical molecular structure of A-amylose. Carbohydrate Research, 61: 7-26.

Yamaguchi, M., Kainuma, K., French, D. 1979. Electron microscopic observations of waxy maize starch. Journal of Ultrastructural Research, 69: 249-261.

Yamin, F.F., Lee, M., Pollak, L.M., White, P.J. 1999. Thermal properties of starch in corn variants isolated after chemical mutagenesis of inbred line B73. Cereal Chemistry, 76: 175-181.

Yoshimura, M., Takaya, T., Nishinari, K. 1999. Effects of xyloglucan on the gelatinization and retrogradation of corn starch as studied by rheology and differential scanning calorimetry. Food Hydrocolloids, 13: 101-111.

Yuan, R.C., Thompson, D.B., Bayer, C.D. 1993. Fine structure of amylopectin in relation to gelatinization and retrogradation behavior of maize starches from three wax-containing genotypes in two inbred lines. Cereal Chemistry, 70: 81-89.

Zeleznak, K.J., Hoseney, R.C. 1986. The role of water in the retrogradation of wheat starch gels and bread crumb. Cereal Chemistry, 63: 407-411.

Zhou, M., Robards, K., Glennie-Holmes, M., Helliwell, S. 1998. Structure and pasting properties of oat starch. Cereal Chemistry, 75: 273-281.

Zobel, H.F., Young, S.N., Rocca, L.A. 1988. Starch gelatinization. An X-ray diffraction study. Cereal Chemistry, 66: 443-446.

Zobel, H.F. 1988a. Starch crystal transformation and their industrial importance. Starch, 40: 1-7.

Zobel, H.F. 1988b. Molecules to granules - a comprehensive starch review. Starh, 40: 44-50. 